Article

\title{
Spatial Market Integration: A Case Study of the Polish-Czech Milk Market
}

\author{
Monika Roman ${ }^{1, *(D)}$ and Zdeňka Žáková Kroupová ${ }^{2}$ (D) \\ 1 Department of Logistics, Institute of Economics and Finance, Warsaw University of Life Sciences, \\ 02-787 Warsaw, Poland \\ 2 Department of Economics, Faculty of Economics and Management, Czech University of Life Sciences in \\ Prague, 16500 Prague, Czech Republic; kroupovaz@pef.czu.cz \\ * Correspondence: monika_roman@sggw.edu.pl
}

Citation: Roman, Monika, and Zdeňka Žáková Kroupová. 2022. Spatial Market Integration: A Case Study of the Polish-Czech Milk Market. Economies 10: 25. https:// doi.org/10.3390/economies10010025

Academic Editor: Sajid Anwar

Received: 18 December 2021

Accepted: 7 January 2022

Published: 13 January 2022

Publisher's Note: MDPI stays neutral with regard to jurisdictional claims in published maps and institutional affiliations.

Copyright: (c) 2022 by the authors. Licensee MDPI, Basel, Switzerland. This article is an open access article distributed under the terms and conditions of the Creative Commons Attribution (CC BY) license (https:// creativecommons.org/licenses/by/ $4.0 /)$.

\begin{abstract}
Analyses of spatial market integration contributes to the knowledge about market efficiency and provides information to policymakers, as the spatial integration of markets contributes to competitiveness and economic development. Although the integration of agri-food markets is widely discussed in the economic literature, research on the dairy sector is relatively limited. This paper fulfils the research gap with an in-depth investigation of spatial milk and dairy product market integration between two neighboring countries-Poland and Czechia-using regional data, and including both production and processing levels. The econometric analysis of time series covering the period 2001-2021 reveals that only long-run milk and skimmed milk powder (SMP) price relationships are between the Czech Republic and Poland. The results of the study confirm that the factors influencing spatial price relationships between the Czech Republic and Poland are: strong trade ties, the common moment of accession to the EU, a close distance between markets, and region specialization.
\end{abstract}

Keywords: spatial integration; market; cointegration; milk; dairy products; Poland; Czechia

\section{Introduction}

The dairy sector is one of the major contributors to the agri-food economy in the European Union (EU). According to Eurostat (2021a), milk production represents $14 \%$ of total agricultural output and the manufacture of dairy products contributes $18 \%$ to the total food production value and $17 \%$ to the total food industry turnover (Čechura and Kroupová 2021). Poland is one of the five major European milk producers, accounting for $8 \%$ of total European milk production (Eurostat 2021a) and contributing 5\% to European dairy production (Eurostat 2021b). Since supply exceeds consumption in the Polish dairy market, Poland is one of the European member states considerably contributing to the EU dairy export (Ministry of Agriculture, Nature and Food Quality 2018). Polish exports are mainly oriented towards the European market and among member states; Germany, with $19 \%$ of the Polish dairy export value, the Czech Republic $(6 \%)$, and Italy $(5 \%)$ are the main recipients of Poland's dairy products (Ministry of Agriculture, Nature and Food Quality 2021). For the Czech Republic, imports of Polish milk and dairy products account for $25 \%$ of all imports of milk and dairy products. Moreover, $6 \%$ of Czech exports of milk flows to Poland. With these shares, Poland is the Czech Republic's second most important foreign partner (after Germany) on the milk market. Cheese dominates the volume and the value of imports from Poland to the Czech Republic (Ministry of Agriculture of the Czech Republic 2021) and in the value of exports to Poland from the Czech Republic, while milk dominates in volume (Czech Statistical Office 2021).

Similarly to Poland, milk and dairy products historically generate a significant proportion of the Czech agri-food sector output (Zdráhal and Bečvářová 2018). Moreover, the dairy sectors in Poland and Czechia were shaped by the same major events; namely the adoption of the market mechanism in 1989, the accession to the EU in 2004, and the 
abolishment of the dairy quota in 2015 (Sobczyński et al. 2015). The adoption of the market mechanism in 1989 fundamentally changed the dairy sector, and both countries faced an initial contraction of milk production; it decreased from 15,860 ths tonnes in Poland, and 4946 ths tonnes in Czechia, in 1989, to 11,927 ths tonnes in Poland, and 2725 ths tonnes in Czechia, in 2003 (Eurostat 2021c). After the accession to the EU on 1 May 2004, milk production began to increase slowly within the limits permitted by the Common Agricultural Policy (CAP). Production reached 13,002 ths tonnes in Poland and 2934 ths tonnes in Czechia in 2014. After the abolition of the milk quotas in April 2015, production continued to increase, reaching 14,831 ths tonnes in Poland, and 3268 ths tonnes in Czechia, in 2020 (Eurostat 2021c). All of this period can be characterized by a considerable decrease in the number of dairy cows. Since 1999 the number of dairy cows has decreased by 35\% in both countries (Eurostat 2021d). Despite this considerable decrease in the dairy cow herd, the level of milk production confirms that the yield per cow has been steadily increasing since 1990 (Čechura et al. 2021).

However, the Polish and Czech dairy sectors are quite heterogeneous regarding size and industrial structure (Philippidis and Waschik 2019). In the Czech Republic, milk production is carried out by large farms. According to Farm Accountancy Data Network (FADN 2021), the average Czech farm specializing in milk production had 117.2 LU (livestock unit) of cows, with a milk yield of $7872 \mathrm{~kg} / \mathrm{cow}$, in 2019 . Conversely, in Poland, the average farm specializing in milk had $17.3 \mathrm{LU}$ of cows with a milk yield of $5901 \mathrm{~kg} / \mathrm{cow}$. It should be noted that more than $2 / 3$ of Czech milk production is produced by farms with mixed production (crops and livestock). While the high degree of diversification allows minimization of the potential risks arising from the dynamics of development on individual commodity markets (Bórawski et al. 2020a highlighted the price volatility in the milk market), specialization of farms can bring the advantage of more knowledge and a higher level of skills (Trnková and Kroupová 2020; Zdráhal and Bečvářová 2018). The low specialization, together with the predominant localization of Czech milk production to less favorable areas, is considered to be the reason why Czech milk production is characterized by significantly higher technical inefficiency than Polish production (Trnková and Kroupová 2020; Rudinskaya et al. 2019). Furthermore, the catching up of Polish best practice is leading to an increase of Polish competitiveness on the international milk and dairy market (Sobczyński et al. 2015), while Czech milk production exhibits a decreasing trend in productivity and competitiveness (Čechura et al. 2021). Technical efficiency and productivity are also important for facing price volatility, which has gained momentum as a result of market liberalization (Thorsøe et al. 2020). According to Bórawski et al. (2020b), the prices for milk paid to farmers have become the most important element of the market, shaping the production of milk and dairy products after the quota abolishment. Milk production has developed well in countries and regions that have met the requirements of the common market and have been competitive.

The regional differences are visible in milk production and processing in both countries. Thorsøe et al. (2020) considers the regional polarization a consequence of dairy market liberalization. Since quotas had limited structural adjustment-in other words, limits to the market mechanisms that force milk production to move to regions with favorable environmental and economic conditions-milk production began to concentrate in regions with a mild climate and a high proportion of grassland after quotas were abolished, as these regions have a comparative advantage. In recent years, $79 \%$ of milk production has taken place in six regions (voivodships) from 16 regions of Poland: Mazowieckie (22\%), Podlaskie (21\%), Wielkopolskie (13\%), Warmińsko-Mazurskie (8\%), Kujawsko-Pomorskie (8\%), and Łódzkie (7\%) (Statistics Poland 2021), see Table 1. These voivodships have developed processing capacity (dairies and dairy cooperatives are concentrated there according to Zuba-Ciszewska 2018), the transportation distance from farmers to processors is relatively short, and they are located close to major cities with considerable consumption capacities (Sobczyński et al. 2015). In the Czech Republic, 71\% of milk production is gained from six regions (see Table 1), namely: Vysočina (19\%), Prague and Central Bohemia (13\%), 
South Bohemia (11\%), Pilsen (11\%), Pardubice (9\%), and Hradec Králové (8\%) (Ministry of Agriculture of the Czech Republic 2020). Similarly to Poland, these are regions characterized by short distances to processing capacities, close to agglomerations and also to the border, especially with Germany and Poland.

Table 1. Raw milk production (the percentage share of total raw milk production in 2020).

\begin{tabular}{|c|c|c|c|}
\hline Poland & $\%$ & Czechia & $\%$ \\
\hline Mazowieckie & 22 & Vysočina & 19 \\
\hline Podlaskie & 21 & Prague and Central Bohemia & 13 \\
\hline Wielkopolskie & 13 & South Bohemia & 11 \\
\hline Warmińsko-Mazurskie & 8 & Pilsen & 11 \\
\hline Kujawsko-Pomorskie & 8 & Pardubice & 9 \\
\hline Łódzkie & 7 & Hradec Králové & 8 \\
\hline Lubelskie & 6 & Olomouc & 7 \\
\hline Pomorskie & 3 & South Moravia & 6 \\
\hline Malopolskie & 2 & Moravian-Silesian & 6 \\
\hline Opolskie & 2 & Zlín & 5 \\
\hline Ślaskie & 2 & Liberec & 2 \\
\hline Świetokrzyskie & 2 & Ústí nad Labem & 2 \\
\hline Dolnoślaskie & 1 & Karlovy Vary & 1 \\
\hline Zachodniopomorskie & 1 & & \\
\hline Podkarpackie & 1 & & \\
\hline Warszawski stoleczny & 1 & & \\
\hline Lubuskie & 1 & & \\
\hline
\end{tabular}

Source: own study based on Statistics Poland (2021) and Ministry of Agriculture of the Czech Republic (2020).

This paper empirically explores the linkages existing between the Polish and Czech milk and dairy product markets, i.e., between markets that are characterized by geographic proximity; this proximity leads to significant foreign trade flows not only in a homogeneous raw material such as milk, but also in homogeneous dairy products (butter, Edam, SMP). The spatial integration of these markets, which can be understood as the flow and transmission of goods and price information across spatially separated markets (Pan and Li 2019), takes place through two channels: (i) the trade flow of unprocessed raw milk and (ii) the trade flow of processed goods-dairy products. The horizontal type of integration has received substantial attention among academics and policymakers over the past decades. The interest in the analysis of the interrelations between geographically separated objects is motivated by the potential welfare and policy implications (Roman 2020). The spatial price behavior of the homogenous product is an important indicator of overall market performance (Kumar and Mishra 2017). Since producer decisions are based on market price information, poorly integrated markets may convey inaccurate price information, leading to inefficient product movements and sub-optimal allocation of resources (Goodwin and Schroeder 1991); this is connected with a reduction in the possibility for a full specialization of countries or regions (Jacks et al. 2011). Poorly integrated markets also choke on the prospective gains from technological change, since without good access to distant markets that can absorb excess local supply, firms' adoption of improved production technologies will tend to cause producer prices to drop; this erases the gains from technological change and thereby dampens incentives for firms to adopt new technologies that can stimulate economic growth (Barrett 2008; Hou and Song 2021). In contrast, strong spatial integration brings benefits. A well-integrated market allows for efficient movement of trade flow that 
stabilizes market prices and reduces the price risk, thanks to flows of surplus to locations characterized by deficits (Gitau and Meyer 2018). According to Hamulczuk et al. (2019), the factor-price equalization theorem stemming from the Heckscher-Ohlin model argues that the full integration of spatially separate product markets should lead to the spatial integration of markets of production factors; consequently, there should be equalization in the wages of workers, rents earned on capital, and prices of land throughout geographically separated objects (e.g., regions or countries). Serra et al. (2006) sum up the benefits of spatial market integration as improvement in the efficiency of resource allocation, reduction in social costs, and maximization of social welfare. Contrarily, spatial market segmentation represents self-sufficiency without trade, has negative effects on the healthy development of markets, increases the deadweight loss incurred by society, and reduces overall economic efficiency (Pan and Li 2019). The benefits of market integration have also been recognized by policymakers and, to facilitate the spatial integration of agri-food markets within the individual member states, enhancing price discovery mechanisms has become one of the most important targets of the European Union's (EU) Common Agricultural Policy (CAP) (Bakucs et al. 2019).

Agri-food market integration has been discussed extensively in the economic literature (e.g., Serra et al. 2006; Frederico 2007; Ihle et al. 2012; Gitau and Meyer 2018; Sobczak et al. 2018; Hamulczuk et al. 2019), both because of the specific nature of agri-food productswhich are characterized by seasonality, perishability, and specific production requirementsand because of the importance of agri-food market integration, as the market efficiency associated with integration enhances the development of rural areas. For example, seasonal production of milk cause seasonality of milk and dairy product prices. According to Kussaiynor and Zhakupova (2019), the prices of milk and dairy products remain high in autumn and winter and decrease in spring and summer. Milk market integration was previously analyzed, especially at the level of vertical market integration (e.g., Fallert et al. 1978; Fałkowski 2010; Serra and Goodwin 2003; Reziti 2014; Kharin 2018; Antonioli et al. 2018; Bełdycka-Bórawska et al. 2021; Bórawski et al. 2021). Research on the spatial integration of the milk market is relatively less frequent (e.g., Goodwin et al. 1999; Jha et al. 2013; Fousekis and Trachanas 2016; Fousekis 2018; Chalmers et al. 2019; JaramilloVillanueva and Palacios-Orozco 2019; Xue et al. 2021). Moreover, the results of these studies cannot be generalized, due to their diversity in terms of methodology, commodities, periods, and countries.

The most important studies that evaluated the spatial integration of milk and dairy product markets in the EU are listed in Table 2. The majority of these studies evaluate market integration employing the price method based on the Law of One Price (LOP) and national price data.

A focus on Poland's milk market (Bakucs et al. 2010) investigated the retail milk price integration in Poland and Hungary between April 1997 and March 2009, employing a Vector Error Correction Model (VECM) and a Threshold Error Correction Model (TECM). Their results confirm neither strong nor weak conditions of the Law of One Price, suggesting that milk price integration between Hungary and Poland is not perfect. More recently, Bakucs et al. (2019) confirmed this result by employing Vector Autoregression Models (VAR) to analyze the spatial integration of the milk market based on a monthly series of raw cows' milk prices from January 2000 to February 2014 in 20 European member states; they found that the so-called New Member States were less integrated compared to the Old Member States and Euro Area member states. Their results also revealed that milk price cointegration is less pronounced than cointegration in other agricultural sectors (e.g., pork prices), and also raised questions about the applicability of national price data. Although the authors believe that regional prices would almost certainly change the results, few studies employed regional price data to analyze spatial market integration of milk and dairy products. One of these studies is by Roman (2020), and assesses the processes of spatial integration on the Polish raw milk market in the period 1999-2018. Her results confirmed a long-term balance between prices in various voivodeships in Poland 
and the role of distance-the closer the voivodeships are to one another, the greater the co-variability of prices is between them. Moreover, she found that Poland's integration processes were associated with: a strong concentration of milk production; the elimination of the smallest farms; investments to improve the competitiveness of dairy farms and processing enterprises; and the association of farmers in producer organizations, in the analyzed period.

Table 2. Empirical studies of spatial milk market integration in Europe.

\begin{tabular}{|c|c|c|c|c|}
\hline Study & Commodity & Level & Country & Years \\
\hline Bakucs et al. (2019) & raw milk & national & $\begin{array}{l}\text { AT, BE, CZ, DE, } \\
\text { DK, ES, FI, FR, } \\
\text { HU, IE, IT, LV, } \\
\text { LT, NL, PL, PT, } \\
\text { RO, SK, SW, UK }\end{array}$ & 2000-2014 \\
\hline Bakucs et al. (2010) & milk & national & PL, HU & 1997-2009 \\
\hline Bakucs and Fertö (2007) & milk & regional & $\mathrm{HU}$ & 2004-2006 \\
\hline Domagała (2020) & SMP & national & $\begin{array}{c}\text { PL, OC, BE, CZ, } \\
\text { DE, IE, LV, NL }\end{array}$ & 2004-2016 \\
\hline Domagała (2021) & butter & national & $\begin{array}{l}\text { PL, BE, CZ, DE, } \\
\text { IE, LT, NL, SK, } \\
\text { IT, FR }\end{array}$ & 2004-2017 \\
\hline $\begin{array}{c}\text { Hillen and von } \\
\text { Cramon-Taubadel (2019) }\end{array}$ & $\begin{array}{c}\text { raw milk, butter, } \\
\text { milk powder, } \\
\text { cheese }\end{array}$ & national & $\mathrm{DE}, \mathrm{CH}$ & 2006-2015 \\
\hline Katrakilidis (2008) & raw milk & national & $\mathrm{BE}, \mathrm{DE}, \mathrm{DK}, \mathrm{FR}$ & 1980-2003 \\
\hline Klepačka et al. (2021) & butter and curd & regional & $\begin{array}{c}\text { PL } \\
\text { BE, CZ DE, FR }\end{array}$ & 2010-2017 \\
\hline Roman (2017) & butter & national & $\begin{array}{l}\text { IR, IT, LV, NL, } \\
\text { PL, SK, UK }\end{array}$ & 2007-2016 \\
\hline Roman and Roman (2020) & raw milk & national & $\begin{array}{c}\text { AT, BE, BG, CZ, } \\
\text { CY, DE, DK, EE, } \\
\text { EL, ES, FI, FR, } \\
\text { HU, IE, IT, NL, } \\
\text { LT, LU, LV, PL, } \\
\text { PT, SI, SK, SW, } \\
\text { UK }\end{array}$ & 2005-2018 \\
\hline Roman (2020) & raw milk & regional & PL & 1999-2018 \\
\hline Tłuczak (2012) & raw milk & national & $\begin{array}{c}\text { CZ, DE, FR, PL, } \\
\text { SK }\end{array}$ & 2004-2010 \\
\hline
\end{tabular}

Note: AT = Austria, BE = Belgium, BG = Bulgaria, CH = Switzerland, CY = Cyprus, CZ = Czechia, DE = Germany $\mathrm{DK}=$ Denmark, EE = Estonia, EL = Greece, ES = Spain, FI = Finland, FR = France, HU = Hungary, IE = Ireland, IT $=$ Italy, LV = Latvia, LT = Lithuania, LU = Luxembourg, NL = the Netherlands, OC = Oceania, PL = Poland, PT = Portugal, $\mathrm{RO}=$ Romania, $\mathrm{SI}=$ Slovenia, $\mathrm{SK}=$ Slovakia, $\mathrm{SW}=$ Sweden, $\mathrm{UK}=$ the United Kingdom.

Instead of the monthly prices used by Roman (2020); Klepačka et al. (2021) used weekly observations from 3 January 2010 to 5 November 2017, to test butter and curd market integration between two neighboring regions with large dairy sectors in Poland (Northern and Central region). Butter and curd have been chosen for their contrasting characteristics: high storability of butter and high perishability of curd. Employing VECM they found that both regions (the surplus-producing North, and the Central with its deficit) were highly integrated in the butter market. Furthermore, based on impulse response analysis, they revealed that the effect of shocks on butter prices was mostly absorbed in two weeks, and prices returned to full equilibrium in about four to five weeks. Contrary to butter, the adjustment of curd prices in one region in reaction to prices in the other region was almost unnoticeable, and the prices of curd seem not to be integrated. The causes of the observed lack of spatial curd price integration could be related to the relatively low price of curd as compared to butter. It seems that the dairy processors adjust curd production after allocating raw milk to the production of butter or other, relatively higher value products. 
The relationship between the Polish and the Czech milk markets was investigated by Tłuczak (2012) who also explored the trade linkages existing between the Polish and the Slovakian/German/French raw milk markets. Applying Vector Autoregressive Models to data from May 2004 to October 2010, she found that milk prices in Poland were dependent on prices in the Czech Republic, Germany, France and Slovakia, while milk prices in the Czech Republic were not dependent on Polish prices. The relationship between the Polish and the Czech raw milk markets (among 24 other member states) was also investigated by Roman and Roman (2020). Employing the VAR model on monthly raw milk prices in 20052018, the authors revealed that the Polish and the Czech raw milk markets were integrated and this linkage was strengthening over time. Moreover, contrary to Tłuczak (2012), they confirmed the bidirectional causality of raw milk prices in Poland and Czechia; however, the key countries determining the price variation in Poland were Germany, Ireland, France, and Slovakia. Integration of the Czech and the Polish markets can also be observed at the level of dairy products. The degree of association between butter prices in Poland and the Czech Republic among 10 selected EU countries using monthly prices was examined by Roman (2017) for the period 2007-2016. Her results confirmed the strong integration of the Czech and the Polish butter prices in the period 2012-2016, and also revealed evidence for the bidirectional causality of butter prices in Poland and Czechia.

It is clear that there is a gap in the research on the assessment of market integration between neighboring EU countries such as Poland and the Czech Republic, where milk production is a traditional part of agri-food production. Filling this research gap requires an analysis of market integration based on regional data, as existing research highlights that the degree of integration is influenced by geographical distance. At the same time, it is appropriate to analyze integration at multiple levels of the value chain. On this basis, this paper attempts to fill a gap in the research on spatial market integration by (i) analyzing spatial market integration between neighboring countries based on regional data; (ii) analyzing market integration on both levels of the value chain - the raw milk market and the processed milk market. The results of this analysis provide important information for the decision-making sphere. Knowing the level of regional market integration allows policy instruments to be targeted to support the building of regional comparative advantage and to promote regional economic development.

The aim of this paper is to assess the spatial integration processes on the milk and dairy product market between Poland and the Czech Republic. As part of the main aim, the authors have sought answers to the following questions: What is the long-run dependence between milk and milk product prices in Poland and the Czech Republic? Is there a longrun balance of milk prices in different regions of Poland and the Czech Republic? In which regions do milk prices have a dominant influence on prices in other areas of Poland and the Czech Republic? What is the direction of the dependence of dairy product prices?

The rest of the paper is organized as follows: Section 2 provides the theoretical background of the spatial market integration; Section 3 introduces the research methodology and datasets; Section 4 presents the results of this study and its discussion; and Section 5 summarizes our findings and provides concluding remarks.

\section{Theoretical Background}

Market integration is a multi-dimensional concept that relates to the flow of goods and information across space, time, and form (González-Rivera and Helfand 2001). The first definition of this concept is attributed to Cournot ([1838] 1897) who stated that an integrated market is an entire territory, the parts of which are so connected by relations of unrestricted trade that prices readily and quickly take the same level throughout the territory. In line with the definition, market integration has three dimensions: vertical (along the supply chain), horizontal (between locations) and intertemporal (between the spot and future or forward markets) (Hamulczuk et al. 2019; Goodwin et al. 2021).

The concept of horizontal or spatial market integration, which is what this paper focuses on, is based on the spatial arbitrage theory and the Law of One Price (McNew 
1996). The process of spatial arbitrage between two spatially separated competitive markets each having their own supply and demand for a homogenous good is described by Van Campenhout (2007) as a process of clearing a common market. If local prices of the homogenous good $\left(P_{i}\right.$ and $\left.P_{j}\right)$ differ between the two markets by more than the cost of transferring the goods between these markets $\left(T_{i j}\right):\left|P_{i}-P_{j}\right|>T_{i j}$, where $i$ and $j$ indicate two spatially separated markets, arbitrageurs will exploit the profit-making opportunities by shipping the good from the market with the low price $\left(P_{j}\right)$ to the market with the high price $\left(P_{i}\right)$. This transfer of goods will increase the demand for goods in the low-price market while increasing supply in the high-price market. The increase in demand with unchanged supply in the low-price market will drive up the price $\left(P_{j}\right)$, while the increased supply at a given level of demand will decrease the price $\left(P_{i}\right)$ in the high-price market. The process of arbitrage will continue until actual prices differ by exactly $T_{i j}$ (Van Campenhout 2007) and arbitrage opportunities are zero (García-Hiernaux et al. 2016). That is, the spatial arbitrage ensures a reaching of unique equilibrium, where local prices in spatially separated markets differ by no more than transportation and transaction costs (Goodwin and Schroeder 1991); these may be determined by, for example, the distance between markets, quality and quantity of transport infrastructure, search costs, and market risk (Svanidze et al. 2021), and no profiting opportunities that would be exploited by arbitrageurs exist (Listorti and Esposti 2012). The lack of arbitrage opportunities is reflected in market efficiency (Dwyer and Wallace 1992). As Frederico (2007) adds, the market is defined as efficient if prices take into account all publicly available information, and there are no opportunities for profit from the exploitation of some information.

The consequence of spatial arbitrage is the Law of One Price, defining that homogeneous goods tend to have the same net price of transportation and transaction costs, when the prices are expressed in the same currency, in markets linked by trade and arbitrage (Fetter 1924). As Hamulczuk et al. (2019) added, the definition of the LOP presented above can be viewed as a weak (relative) notation of the LOP, that can be defined as $P_{i, t}-P_{j, t}=T_{i j, t}$, where $t$ denotes time (Baulch 1997). The strong (absolute) notation does not take into account transfer costs, and assumes full and immediate price transmission with zero price differences, that is: $P_{i}=P_{j}$ in any time $t$ (Hamulczuk et al. 2019; García-Hiernaux et al. 2016). The LOP can be viewed as a criterion of market integration (Gluschenko 2021), and an important condition for the efficient functioning of markets under assumptions of the lack of: trade barriers, market power, product heterogeneity and perishability, exchange rate risks, and imperfect flow of information (Listorti and Esposti 2012). A violation of the LOP is an instance of inefficiency which may delay specialization according to the comparative advantage and, thus, cause welfare losses (Frederico 2007).

In this paper, the LOP is applied to analyze the spatial integration of Poland and Czech milk and dairy product markets. According to Van Campenhout (2007) and Frederico (2007) we define these markets as integrated if prices in these countries are determined simultaneously in the long-run, since the dynamics of economic processes can lead to temporary deviations from equilibria (e.g., due to seasonality of agricultural commodities McNew 1996); this means that in the short-run, price differences may exceed the transfer costs in competitive markets (Roman 2020). Two relevant mechanisms are behind this price adjustment: physical trade of the good, and information flow that occurs between the locations (Hamulczuk et al. 2019); according to Listorti and Esposti (2012), the information flow might explain price transmission even more than physical trade flows.

Empirical analyses use several methods to evaluate spatial market integration based on price adjustment between markets. According to Van Campenhout (2007), the first attempts at this evaluation were based on the strong notation of the LOP and took price correlation coefficient as a measurement of the degree of market integration. This simple regression and correlation analysis has been criticized due to two main conceptual and practical problems: the endogeneity of prices and the dynamism of price adjustments associated with temporary deviations from equilibrium (Fackler 1996). As a reaction to this criticism, dynamic regression models gained increasing attention because they allow 
representation of contemporaneous and lagged price linkages, and take price endogeneity into account (Van Campenhout 2007). The dynamic model framework (e.g., Ravallion 1986) applied in this study assesses market integration employing cointegration analysis. In addition, the authors used the Error Correction Model (ECM), the Granger causality test to examine the direction of the relationship, and the Impulse Response Function (IRF) to determine the response to price shocks of individual dairy products. This allowed us to investigate the short-run dynamics that are consistent with the long-run relationship (Goodwin et al. 2021).

The analysis of market integration can provide a lot of economically and politically important information. The measurement of market integration is an essential tool for understanding the functioning of markets (Ravallion 1986). Knowledge of spatial integration helps economists explain whether the market moves commodities towards their higher value users, whether it is able to absorb large shocks without breakdown, and whether the market fosters development through specialization (Fackler 1996). With the knowledge of market integration, it is possible to evaluate the speed of transmission, which makes it easier to forecast prices in particular markets (Roman 2020). Moreover, the understanding of spatial markets also increases the knowledge of price relationships in a vertical chain, since spatial transformations are representative of input/output relationships (Fackler 1996). Cognition of the level and strength of market integration is also essential for economic policy aimed at creating the conditions to achieve an efficient market system (Hamulczuk 2020) and for the building of comparative advantages (Hou and Song 2021). An efficient agricultural and food market is a prerequisite for food security (Habte 2017; Svanidze et al. 2021) as it reduces the exposure of producers and consumers to unexpected fluctuations in local supplies of raw materials and processed products (Hamulczuk 2020).

\section{Methodology}

The integration analysis was conducted on the monthly prices of four dairy products: fresh milk, butter, Edam cheese, and skimmed milk powder (SMP). The temporal scope of the study covered the period 2001-2021 at the national level, and the period 2013-2021 at the regional level. The time ranges were selected based on available data. The quantitative analysis is based on logarithmic transformations of prices (log-prices) and their first differences (log-returns). Country-level data were obtained from Italian Dairy Economic Consulting (CLAL.IT 2021) and Food and Agriculture Data (FAO 2021). Data at the regional level were obtained from the Czech Statistical Office (2021) and Polish Statistical Office (2021). Country and region abbreviations have been used in the presentation of results: Czech Republic (CZ), Poland (PL), Jihočeský kraj (JHC), Jihomoravský kraj (JHM), Karlovarský kraj (KVK), Kraj Vysočina (VYS), Královéhradecký kraj (HKK), Liberecký kraj (LBK), Moravskoslezský kraj (MSK), Olomoucký kraj (OLK), Pardubický kraj (PAK), Plzeňský kraj (PLK), Středočeský kraj (STC), Zlínský kraj (ZLK), Dolnośląskie Voivodeship (DOL), Kujawsko-Pomorskie Voivodeship (K-P), Łódzkie Voivodeship (LDZ), Lubelskie Voivodeship (LBL), Lubuskie Voivodeship (LBU), Małopolskie Voivodeship (MLP), Mazowieckie Voivodeship (MAZ), Opolskie Voivodeship (OPO), Podkarpackie Voivodeship (PKR), Podlaskie Voivodeship (PDL), Pomorskie Voivodeship (POM), Śląskie Voivodeship (SL), Świętokrzyskie Voivodeship (SW), Warmińsko-Mazurskie Voivodeship (W-M), Wielkopolskie Voivodeship (WLK), Zachodnio-Pomorskie Voivodeship (Z-P). The locations of Polish and Czech regions are shown in Figure 1.

One of the first analyses was cointegration testing, according to which nonstationary time series are integrated if their linear combination is stationary. Then, we speak of a long-run equilibrium relationship between the price series being studied. Cointegration means that analyzed prices move closely together in the long-run perspective, while in the short-run they may drift apart. For this purpose, the Johansen procedure, which is based on a vector autoregression (VAR) model, was used. The general form of the VAR model is as follows (Neusser 2016): 


$$
X_{t}=C+\sum_{i=1}^{p} A_{i} X_{t-i}+e_{t}
$$

where $X_{t}$ is the endogenous variable vector, $C$ is the constant vector, $A_{i}$ forms the coefficient matrix, and $e_{t}$ is the white noise vector that is independently and identically distributed with $e_{t} \sim \operatorname{IID}(0, \Sigma)$, where $\Sigma$ is the positive definite matrix.

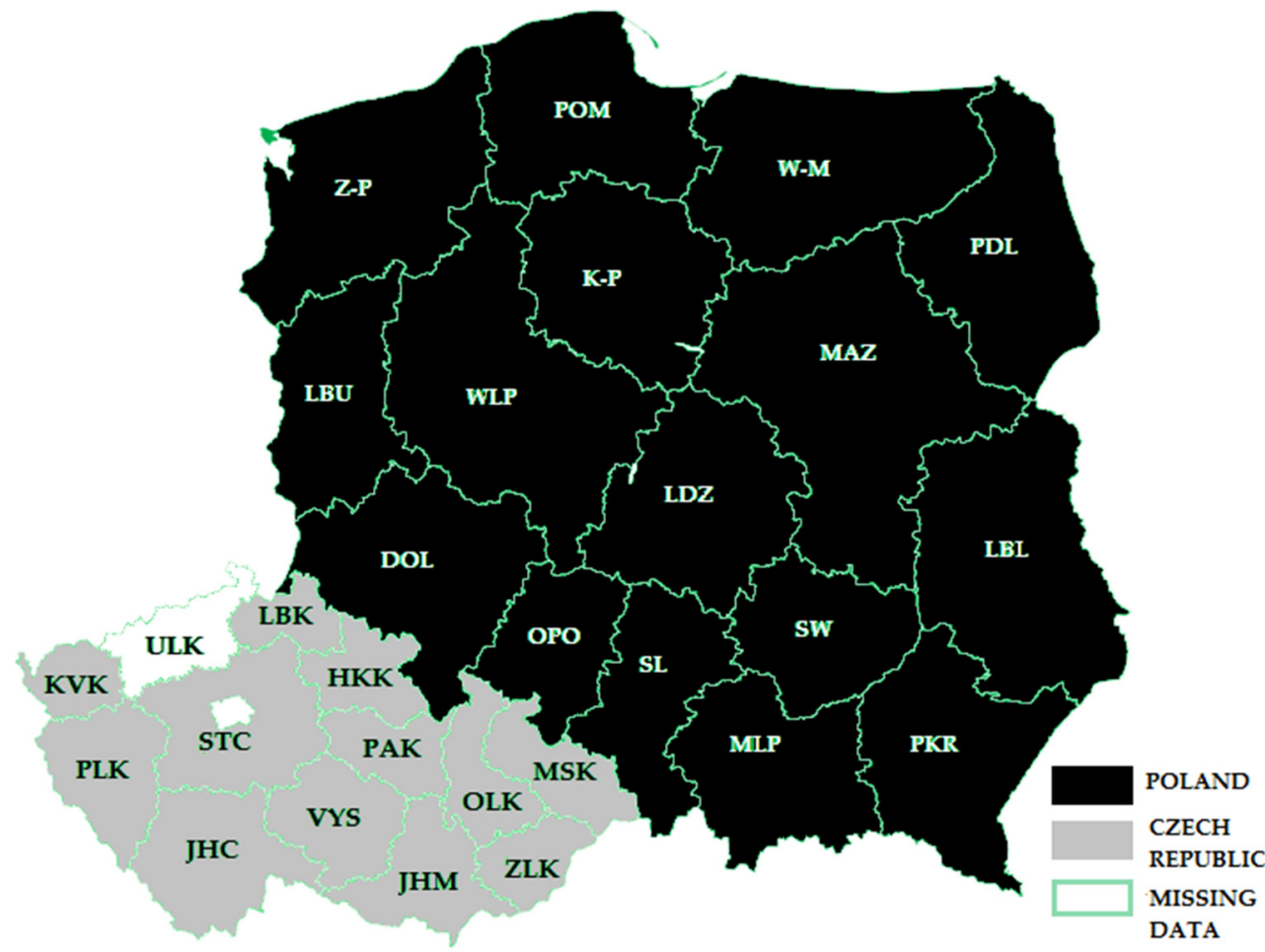

Figure 1. Map of analyzed regions.

In this work, the price cointegration analysis covered a maximum of two markets (A and B). The VAR model, with an intercept and without other deterministic variables for product prices in markets $A$ and $B$, can be written as a system of two equations:

$$
\begin{gathered}
X_{A t}=\alpha_{A 0}+\sum_{i=1}^{p} \alpha_{A i} X_{A t-i}+\sum_{i=1}^{p} \beta_{A i} X_{B t-i}+e_{A t}, \\
X_{B t}=\alpha_{B 0}+\sum_{i=1}^{p} \alpha_{B i} X_{A t-i}+\sum_{i=1}^{p} \beta_{B i} X_{B t-i}+e_{B t},
\end{gathered}
$$

where: $\alpha, \beta$ are the parameters of the model in the equation of prices on market $A$ and prices on market $B$.

Before the analysis of long-run relationships, statistical properties of price series were carried out. Unit root tests are applied to residuals from the cointegrating regression which are used for checking that price series have the same order. If both analyzed price series have the same integration order, then a test for cointegration can be performed. The modified Augmented Dickey-Fuller test (ADF-GLS) and the Phillips-Perron (PP) test were used to evaluate the unit root. In both tests, the null hypothesis was that the time series are nonstationary; the alternative hypothesis was that they are stationary. The ADF-GLS test is a modification of the ADF test suggested by Elliott et al. (1996). In the first step, the $y_{t}$ series is trendless and decreased using a generalized least squares method. In the second, the remainders of the equation $\left(\widetilde{y_{t}}\right)$ are used to test the unit root using the ADF equation:

$$
\Delta \widetilde{y}_{t}=\rho \widetilde{y}_{t-1}+\sum_{i=1}^{p} \delta_{i} \Delta \widetilde{y}_{t-p}+\varepsilon_{t}
$$


where: $\rho$ and $\delta$ are the model coefficients, $\varepsilon_{t}$ is the random component, and $p$ is the maximum augmentation lag. The Phillips-Perron unit root test is also a modification of the Dickey-Fuller test. Instead of accounting for autoregressive structure, the PP test corrects for any series correlation and heteroscedasticity in the errors by modifying the Dickey-Fuller test statistics in a non-parametric manner (Phillips and Perron 1988). The lag length for the tests was selected using the Akaike Information Criterion (AIC). Details of the time series tested and verification of the degree of integration are provided in Table A1 in Appendix A. Note that all the time series were integrated at order I(1), except for monthly cheese prices in Poland and the Czech Republic, whose order was I(0).

If the variables are cointegrated, the Equation (1) can be represented in the vector error correction model (VECM) $(p-1)$ (Neusser 2016):

$$
\Delta\left(X_{t}\right)=C+\Pi X_{t-1}+\sum_{i=1}^{p-1} \tau_{i} \Delta\left(X_{t-1}\right)+e_{t}
$$

where: $\Pi=\sum_{i=1}^{p-1} A_{i}-I$ (I: identity matrix); $\Gamma_{i}=-\sum_{j=i+1}^{p-1} A_{i} ; \Pi$ is the long-run matrix coefficient, $\Gamma_{i}$ is the short-run matrix coefficient. The VECM model (with an unlimited constant) for two series of prices in locations $A$ and $B$, assuming that the cointegration vector has the form $[1,-1]$, can be written as a system of the following two equations:

$$
\begin{gathered}
\Delta\left(X_{A t}\right)=\alpha_{A 0}+\rho_{A}\left(X_{A t-1}-X_{B t-1}\right)+\sum_{i=1}^{p-1} \alpha_{A i} \Delta X_{A t-i}+\sum_{i=1}^{p-1} \beta_{A i} \Delta X_{B t-i}+e_{A t} \\
\Delta\left(X_{B t}\right)=\alpha_{B 0}+\rho_{B}\left(X_{A t-1}-X_{B t-1}\right)+\sum_{i=1}^{p-1} \alpha_{B i} \Delta X_{A t-i}+\sum_{i=1}^{p-1} \beta_{B i} \Delta X_{B t-i}+e_{B t}
\end{gathered}
$$

where: $\rho$ is the parameter of the model in the equation of prices on market $A$ and prices on market $B$, with the rest of the markings as in Equations (1)-(3).

One of two tests are used in the Johansen procedure: the trace test $\left(L R_{\text {trace }}\right)$ or the maximum eigenvalue test $\left(L R_{\max }\right)$ :

$$
\begin{gathered}
L_{\text {trace }}(r)=-(T-p) \sum_{i=r+1}^{k} n\left(1-\lambda_{i}\right), \\
L R_{\text {max }}(r)=-(T-p) \ln \left(1-\lambda_{r+1}\right),
\end{gathered}
$$

where: $r$ is the number of cointegrating relationships, $T$ is the sample size, $k$ is the number of variables, $\lambda_{i}$ is the $i$-th largest canonical correlation, $p$ is the maximum augmentation lag. The $L R_{\text {trace }}$ tests the null hypothesis of $r$ cointegrating vectors against the alternative hypothesis of $n$ cointegrating vectors. The $L R_{\max }$ tests the null hypothesis of $r$ cointegrating vectors against the alternative hypothesis of $r+1$ cointegrating vectors.

As a result of applying the Johansen test, we may have the following situations: (1) the rank of the matrix $\Pi$ is equal to 0 and then the Equation (5) is a VAR model for increments of variables in which there is no long-run dependence; (2) the rank of the matrix $\Pi$ is greater than 0 but less than $r$, then the number of cointegration vectors is equal to this rank; (3) the matrix $\Pi$ is of full rank, then the series of variables is stationary and, thus, the Equation (5) is a VAR model for the levels of variables.

In the next step, a VAR or VECM model was estimated depending on the results from the Johansen test. In the next step, if significant coefficients from endogenous variables were found by estimation, the Granger causality test and impulse response function (IRF) test were performed. It allowed assessment of the possible direction of price transmission. The Granger causality test detects the causal relationship between the variables being studied. In this test, variable $X$ is a cause, in the Granger sense, of variable $Y$, when the values of variable $Y$ can be better predicted given the future value of variable $X$ than without those values. This test can be described by the following equations (Granger 1969): 


$$
\begin{aligned}
& Y_{t}=\beta_{0}+\sum_{j=1}^{m} \beta_{j} Y_{t-j}+\sum_{k=l}^{n} \beta_{k} X_{t-k}+u_{t}, \\
& X_{t}=\beta_{0}+\sum_{j=1}^{m} \beta_{j} X_{t-j}+\sum_{k=l}^{n} \beta_{k} Y_{t-k}+u_{t}
\end{aligned}
$$

where: $Y_{t}$ is the value of variable $Y ; X_{t}$ is the value of variable $X ; \beta$ denotes the structural parameters of the model; $t$ is the change in time; $u_{t}$ is the random component of the model.

The impulse response function indicates how fast a price shock at one price transmits towards another price. It is the response of one price variable to a sudden and temporary change in another price variable.

\section{Preliminary Analysis of Polish and Czech Milk and Dairy Markets}

\subsection{Trade Exchange}

The degree of integration of separate markets can be characterized using an analysis of changes in trade. The flow of products between different markets expresses the flow of supply and demand impulses that occur between countries/regions (Hamulczuk 2020). Both the Czech Republic and Poland are increasing their trade volume in all dairy products year by year. Milk and dairy products are perishable products with low transport and storage susceptibility. Therefore, they require continuous cold chain maintenance which can limit the transportation distance of these products. However, it is worth noting that advances in logistics have significantly increased the ability to transport milk and dairy products, with low transport and storage vulnerability over much longer distances (Roman 2018).

However, the main trading partners of the Czech Republic and Poland are mostly neighboring countries (Table 4). In addition, the Czech Republic and Poland are also key partners for each other. Czechs imported cheese (25\% of import value), butter ( $24 \%$ of value), milk (10\% of value), and SMP ( $9 \%$ of value) from Poland. Depending on the product, Poland is the first, second, or, in the worst case, third largest supplier for the Czech Republic in terms of import value. Poland imported the most of the SMP ( $22 \%$ of value), milk (20\% of value), and cheese (7\% of value) from Czech Republic. The Czech Republic is the second, third, or fourth largest supplier of dairy products in terms of import value.

Table 3. Dairy product exports and imports from/to the Czech Republic and of Poland from/to other

\begin{tabular}{|c|c|c|c|c|c|c|c|c|c|c|c|c|c|c|c|}
\hline \multicolumn{8}{|c|}{ Export } & \multicolumn{8}{|c|}{ Import } \\
\hline \multicolumn{4}{|c|}{ Czech Republic } & \multicolumn{4}{|c|}{ Poland } & \multicolumn{4}{|c|}{ Czech Republic } & \multicolumn{4}{|c|}{ Poland } \\
\hline Code & 2005 & 2013 & 2019 & Code & 2005 & 2013 & 2019 & Code & 2005 & 2013 & 2019 & Code & 2005 & 2013 & 2019 \\
\hline \multicolumn{16}{|c|}{ Milk, whole fresh cow milk } \\
\hline $\mathrm{DE}$ & 0.71 & 0.59 & 0.72 & $\mathrm{DE}$ & 0.93 & 0.64 & 0.53 & SK & 0.39 & 0.42 & 0.39 & LT & 0.00 & 0.66 & 0.40 \\
\hline SK & 0.17 & 0.18 & 0.10 & $\mathrm{CN}$ & 0.00 & 0.02 & 0.14 & $\mathrm{DE}$ & 0.08 & 0.43 & 0.37 & DE & 0.23 & 0.15 & 0.29 \\
\hline IT & 0.07 & 0.10 & 0.05 & LT & 0.02 & 0.04 & 0.04 & PL & 0.50 & 0.06 & 0.10 & $\mathrm{CZ}$ & 0.34 & 0.15 & 0.20 \\
\hline PL & 0.01 & 0.04 & 0.04 & UK & 0.00 & 0.04 & 0.04 & $\mathrm{BE}$ & 0.00 & 0.01 & 0.05 & AT & 0.00 & 0.00 & 0.04 \\
\hline $\mathrm{HU}$ & 0.02 & 0.05 & 0.03 & $\mathrm{ZA}$ & 0.00 & 0.00 & 0.03 & FR & 0.00 & 0.07 & 0.02 & NL & 0.00 & 0.01 & 0.03 \\
\hline OTH & 0.02 & 0.05 & 0.06 & OTH & 0.05 & 0.26 & 0.22 & OTH & 0.02 & 0.01 & 0.06 & OTH & 0.42 & 0.03 & 0.03 \\
\hline \multicolumn{16}{|c|}{ Butter, cow milk } \\
\hline SK & 0.19 & 0.38 & 0.64 & $\mathrm{CZ}$ & 0.02 & 0.18 & 0.20 & PL & 0.06 & 0.19 & 0.44 & NL & 0.04 & 0.34 & 0.32 \\
\hline IT & 0.06 & 0.31 & 0.23 & $\mathrm{DE}$ & 0.24 & 0.12 & 0.11 & $\mathrm{DE}$ & 0.37 & 0.43 & 0.24 & $\mathrm{DE}$ & 0.25 & 0.34 & 0.27 \\
\hline PL & 0.02 & 0.02 & 0.05 & NL & 0.17 & 0.11 & 0.10 & SK & 0.10 & 0.18 & 0.16 & IE & 0.00 & 0.05 & 0.10 \\
\hline HU & 0.05 & 0.05 & 0.02 & SK & 0.03 & 0.14 & 0.09 & $\mathrm{BE}$ & 0.03 & 0.12 & 0.11 & $\mathrm{BE}$ & 0.14 & 0.05 & 0.09 \\
\hline ES & 0.00 & 0.00 & 0.02 & $\mathrm{BE}$ & 0.18 & 0.07 & 0.01 & NL & 0.07 & 0.04 & 0.02 & DK & 0.02 & 0.06 & 0.07 \\
\hline OTH & 0.68 & 0.25 & 0.05 & OTH & 0.35 & 0.38 & 0.49 & OTH & 0.36 & 0.04 & 0.03 & OTH & 0.54 & 0.16 & 0.16 \\
\hline
\end{tabular}
countries (five best trade partners by value), in \%. 
Table 4. Dairy product exports and imports from/to the Czech Republic and of Poland from/to other countries (five best trade partners by value), in \%.

\begin{tabular}{|c|c|c|c|c|c|c|c|c|c|c|c|c|c|c|c|}
\hline \multicolumn{8}{|c|}{ Export } & \multicolumn{8}{|c|}{ Import } \\
\hline \multicolumn{4}{|c|}{ Czech Republic } & \multicolumn{4}{|c|}{ Poland } & \multicolumn{4}{|c|}{ Czech Republic } & \multicolumn{4}{|c|}{ Poland } \\
\hline Code & 2005 & 2013 & 2019 & Code & 2005 & 2013 & 2019 & Code & 2005 & 2013 & 2019 & Code & 2005 & 2013 & 2019 \\
\hline \multicolumn{16}{|c|}{ Cheese, whole cow milk } \\
\hline IT & 0.27 & 0.34 & 0.43 & $\mathrm{DE}$ & 0.20 & 0.12 & 0.15 & $\mathrm{DE}$ & 0.34 & 0.44 & 0.37 & $\mathrm{DE}$ & 0.39 & 0.46 & 0.39 \\
\hline SK & 0.19 & 0.25 & 0.23 & $\mathrm{CZ}$ & 0.15 & 0.12 & 0.13 & PL & 0.34 & 0.27 & 0.25 & NL & 0.05 & 0.12 & 0.14 \\
\hline PL & 0.02 & 0.09 & 0.12 & IT & 0.14 & 0.11 & 0.10 & SK & 0.18 & 0.09 & 0.14 & IT & 0.08 & 0.09 & 0.11 \\
\hline $\mathrm{AE}$ & 0.10 & 0.05 & 0.03 & UK & 0.03 & 0.06 & 0.07 & IT & 0.03 & 0.06 & 0.09 & $\mathrm{CZ}$ & 0.01 & 0.06 & 0.07 \\
\hline SA & 0.04 & 0.03 & 0.03 & SK & 0.05 & 0.08 & 0.07 & NL & 0.03 & 0.06 & 0.05 & FR & 0.09 & 0.08 & 0.07 \\
\hline OTH & 0.38 & 0.25 & 0.16 & OTH & 0.43 & 0.52 & 0.46 & OTH & 0.08 & 0.08 & 0.10 & OTH & 0.38 & 0.19 & 0.23 \\
\hline \multicolumn{16}{|c|}{ Milk, skimmed cow milk } \\
\hline SK & 0.67 & 0.39 & 0.54 & $\mathrm{DE}$ & 0.31 & 0.04 & 0.53 & DE & 0.11 & 0.22 & 0.44 & $\mathrm{LT}$ & 0.95 & 0.36 & 0.25 \\
\hline $\mathrm{DE}$ & 0.28 & 0.16 & 0.23 & $\mathrm{CN}$ & 0.00 & 0.02 & 0.09 & SK & 0.78 & 0.17 & 0.32 & $\mathrm{CZ}$ & 0.00 & 0.36 & 0.22 \\
\hline PL & 0.00 & 0.08 & 0.13 & IT & 0.00 & 0.02 & 0.08 & PL & 0.09 & 0.59 & 0.09 & $\mathrm{BE}$ & 0.00 & 0.00 & 0.20 \\
\hline IT & 0.02 & 0.11 & 0.04 & FR & 0.00 & 0.00 & 0.05 & NL & 0.00 & 0.00 & 0.09 & $\mathrm{DE}$ & 0.00 & 0.10 & 0.19 \\
\hline $\mathrm{RO}$ & 0.00 & 0.06 & 0.03 & $\mathrm{RO}$ & 0.00 & 0.02 & 0.05 & UK & 0.00 & 0.01 & 0.03 & SW & 0.00 & 0.00 & 0.05 \\
\hline OTH & 0.02 & 0.19 & 0.03 & $\mathrm{OTH}$ & 0.69 & 0.89 & 0.20 & $\mathrm{OTH}$ & 0.01 & 0.01 & 0.03 & OTH & 0.05 & 0.18 & 0.09 \\
\hline
\end{tabular}

Note: Country codes are based on ISO 3166: AE = the United Arab Emirates, AT = Austria, BE = Belgium, $\mathrm{CN}=$ China, $\mathrm{CZ}=$ Czech Republic, $\mathrm{DE}=$ Germany, $\mathrm{DK}=$ Denmark, $\mathrm{ES}=$ Spain, $\mathrm{FR}=$ France, $\mathrm{HU}=$ Hungary, $\mathrm{IE}=$ Ireland, $\mathrm{IT}=$ Italy, $\mathrm{LT}=$ Lithuania, NL $=$ the Netherlands, OTH = Others, $\mathrm{PL}=$ Poland, $\mathrm{RO}=$ Romania SA = Saudi Arabia, $\mathrm{SK}=$ Slovakia, $\mathrm{SW}=$ Sweden, $\mathrm{UK}=$ the United Kingdom, ZA = South Africa. Source: own calculation (FAO 2021).

In 2019, Czechs exported the most of the SMP (13\% of export value) and cheese (12\% of value) to Poland. In the case of Poland, the Czech Republic's share in butter exports amounted to $20 \%$ and, at the same time, it was the main foreign recipient of this product. Moreover, $13 \%$ of the cheese exported from Poland went to the Czech Republic, which was the second largest trade partner with respect to this product.

Therefore, on the basis of trade flows, it would be reasonable to conclude that these countries are characterized by a long range of linkages, continuously present. Therefore, this means that there are strong grounds with respect to the integration of the two markets.

\subsection{The Linkage of Milk Prices between Regions in Poland and the Czech Republic}

The preliminary analysis of market integration can be also conducted based on price analysis. If there are significant price differences between the analyzed markets, then there is a weak integration. Moreover, these differences often increase as distances between the separate markets being analyzed increase (Roman 2020). Average deviations of logarithms of Polish milk prices from Czech prices over the entire period ranged from $-9.1 \%$ to $+3.2 \%$, with an average of $-2.0 \%$ (Figure 2). In addition, note the sub-period of the largest price deviations occurring between 2002 and 2005, i.e., especially before the accession of both countries to the EU. Over a longer period, milk prices in Poland were only higher than milk prices in the Czech Republic in 2016-2017. This may have been due to changes in the CAP, including the abolition of milk quotas and the period of adjustment to the new milk market situation (Eurostat 2021e). Decreasing differences in milk prices in time are probably a consequence of the influence of various factors, such as the increase in the foreign trade of milk and dairy products between Poland and the Czech Republic. In addition, the change in milk price differences was influenced by a more efficient information flow after both countries joined the EU, as well as by the increasing price integration across EU countries (Benedek et al. 2017; Fousekis 2018). 


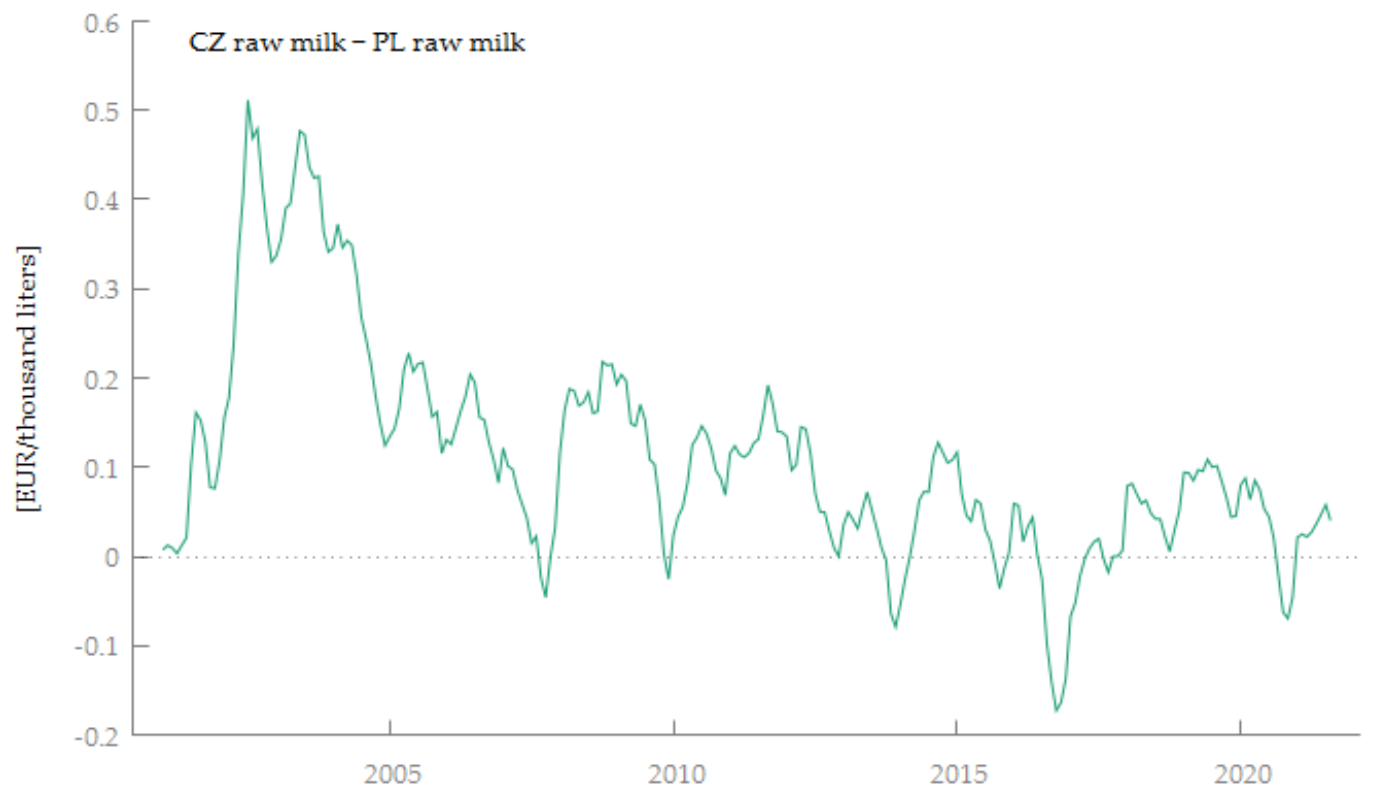

Figure 2. Differences between Czech and Polish milk prices in 2001-2021 (logarithm price). Source: own calculation (Czech Statistical Office 2021; Polish Statistical Office 2021).

\subsection{Linking the Prices of Dairy Products between the Polish and Czech Markets}

The final part of the preliminary analysis focuses on the price linkages of dairy products between the Czech Republic and Poland. The average deviations of the logarithms of Polish butter prices from Czech prices over the entire period ranged from $-9.2 \%$ to $+6.4 \%$, with an average of $-1.5 \%$ (Figure $3 a$ ). The largest variation in butter prices occurred between 2002 and 2005, which was similar for milk prices. The average deviations of the logarithms of Polish SMP prices from Czech prices over the entire period ranged from $-4.4 \%$ to $+2.5 \%$, with an average of $-0.6 \%$ (Figure $3 b$ ). Thus, it should be said that the price differences were the smallest for this product. The largest SMP price deviations occurred between 2002 and 2005. The average deviations of the logarithms of Polish Edam cheese prices from Czech prices over the entire period ranged from $-4.4 \%$ to $+2.7 \%$, with an average of $-1.6 \%$ (Figure 3c). The largest SMP price deviations also occurred between 2002 and 2005.

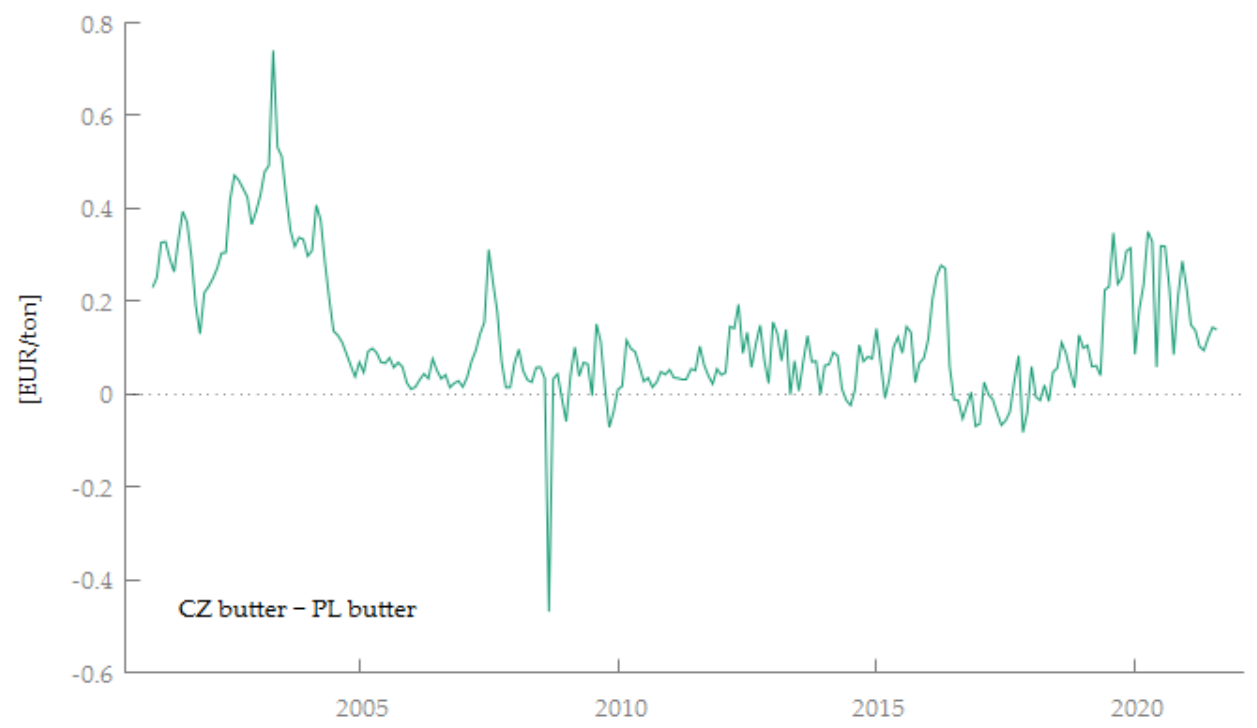

(a)

Figure 3. Cont. 


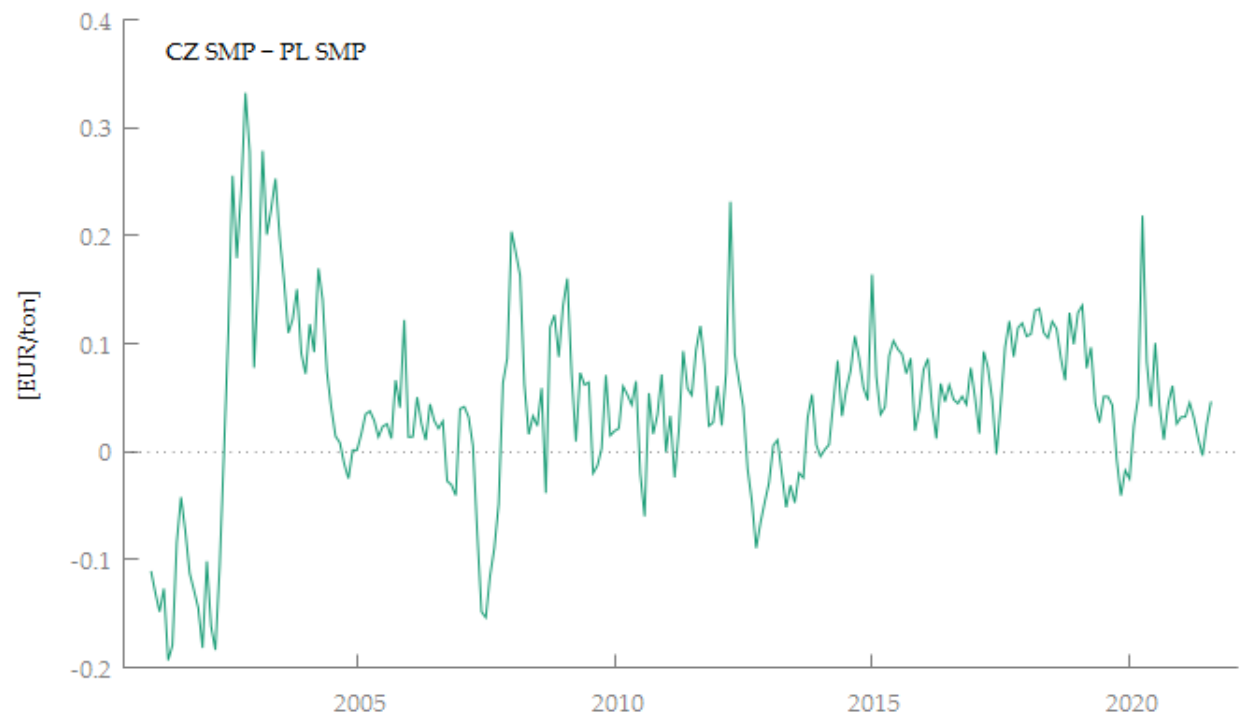

(b)

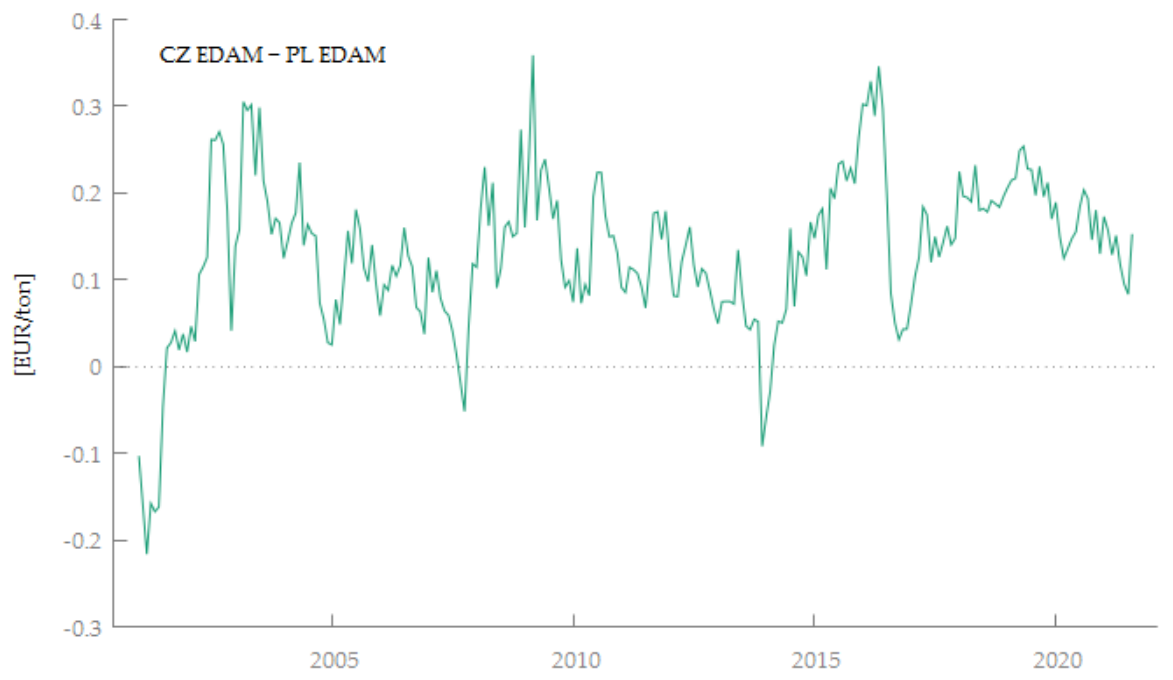

(c)

Figure 3. The price difference between dairy products: (a) butter, (b) SMP, (c) Edam, in Poland and the Czech Republic. Source: own calculations (CLAL.IT 2021).

\section{Results and Discussion}

\subsection{Milk Market Integration of Regions in Poland and the Czech Republic}

Since the milk price series were characterized by first-order I(1) integration, the first step was to perform a Johansen cointegration test. The test was used to verify the long-run relationship between milk price at the national level, then at the regional level. The results of the cointegration test for milk prices at the national level are summarized in Table 5. Note that the statistical values of the tests are greater than their critical values at $p=0.05$. This means that there is a long-run cointegration relationship between the Czech milk price and the Polish milk price at the national level. Since there was one cointegrating rank in the milk price relationship, the VECM model was used. It can be seen that the coefficient estimates in the long-run equilibrium relationship range from 0.51 to 0.67 . The coefficient in the long-run relationship in the model with a limited trend and an unlimited constant is 0.67 , which indicates that, in the long-run relationship, a $1 \%$ increase/decrease in milk prices in the Czech Republic is reflected by $0.67 \%$ increase/decrease in milk prices in Poland. Czech milk prices are an exogenous variable for Polish milk prices, as the only 
significant coefficient with deviations from long-run equilibrium (EC) is in the Czech milk price equation. Imbalances due to shocks in the price system are corrected during the month by $6.3 \%$ through the Czech Republic's response, and by $2.5 \%$ through the Polish price response. Moreover, in the light of the Granger test performed, it can be concluded that future prices in the Czech Republic are a cause, in the Granger sense, of future milk prices in Poland and vice versa. Thus, we identify a two-way causality. Moreover, the reaction of Czech milk prices to Polish milk prices is positive and stable over 8 months (Figure 4). However, the reaction of milk prices in Poland to milk prices in the Czech Republic is shorter and lasts about 3 months.

Table 5. Cointegration testing results and selected VECMs statistics for the Czech Republic and Poland's raw milk price series.

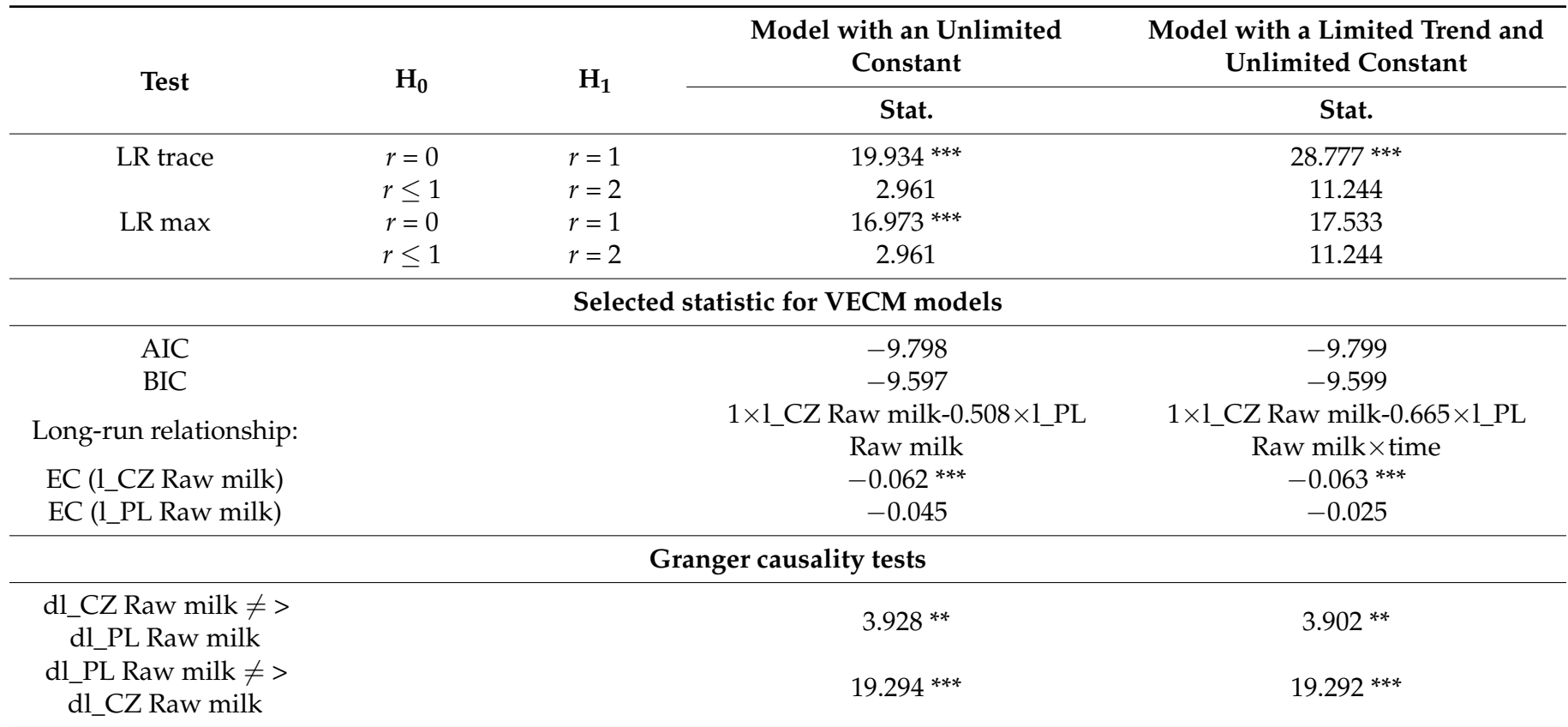

Note: $\mathrm{r}=$ rank; 1 = price logarithm; $\mathrm{dl}=$ first differences of price logarithms; $1{ }^{*}$ __CZ Raw milk-0.508*1_PL Raw milk which indicates that, in the long-run relationship, $1 \%$ increase/decrease in milk prices in the Czech Republic is reflected by a $0.508 \%$ increase /decrease in milk prices in Poland; EC (1_CZ Raw milk) = error correction component for Czech raw milk prices; EC (1_PL Raw milk) = error correction component for Polish raw milk prices; dl_CZ Raw milk $\neq>$ dl_PL Raw milk means whether future milk prices in the Czech Republic are the cause, in the sense of Granger, of future milk prices in Poland; dl_PL Raw milk $\neq>$ dl_CZ Raw milk means whether future milk prices in Poland are the cause, in the sense of Granger, of future milk prices in the Czech Republic. ${ }^{* *} p<0.05$, ${ }_{* * *}^{*} p<0.01$. Source: own calculation (Czech Statistical Office 2021; Polish Statistical Office 2021).

Results of cointegration testing at the regional level are shown in Table A2 in Appendix A. Cointegration testing for the regions involved a pairwise analysis of each Czech region with each Polish region. In this case, the highest number of long-run relationships was identified for the Czech side: Liberecký kraj (11 long-run linkages), Královéhradecký kraj (8 linkages), and for the Polish side: Warmińsko-Mazurskie Voivodeship (9 linkages) and Podlaskie Voivodeship (8 linkages). In the case of the Czech Republic, these are the regions closest to Poland. The importance of distance was also confirmed by analyzing the correlation of milk prices in each region and the distance between these regions (Figure 5). According to this, as distance increases, the degree of milk price linkage decreases. However, in the case of Poland, the highest number of long-run linkages was obtained by regions farthest from the Czech border; however, in turn, these regions are key from the point of view of Polish milk production. Thus, both the distance and the specialization of the region can be considered as a factor influencing the integration processes of separate markets. 


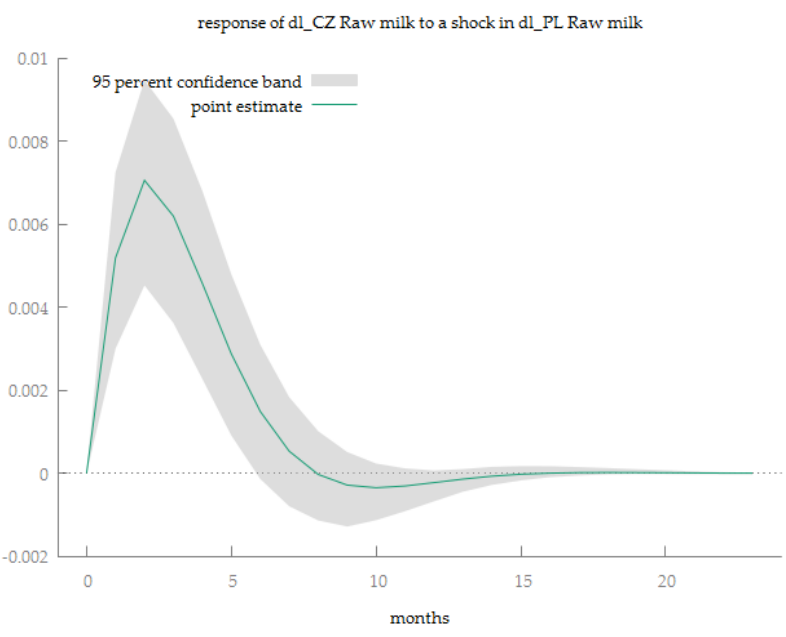

(a)

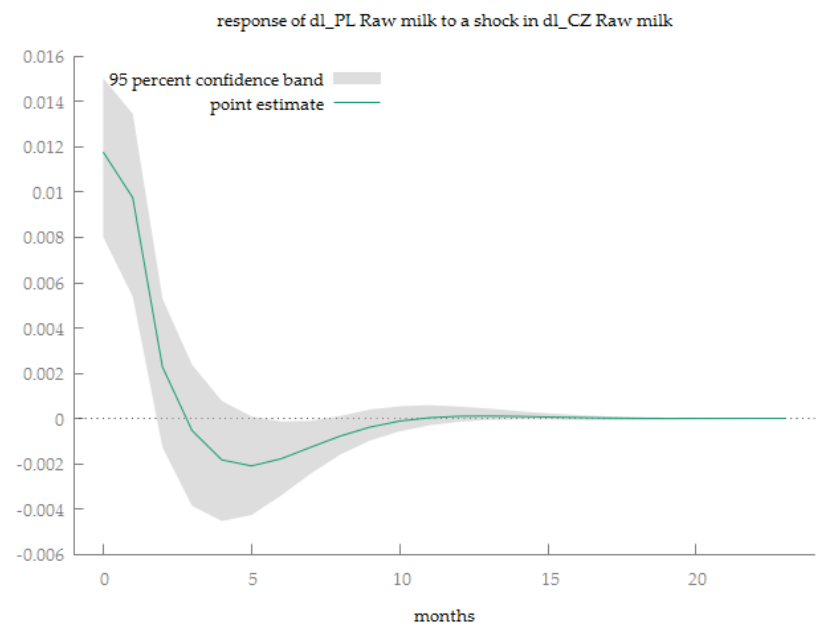

(b)

Figure 4. Impulse response function between raw milk prices: (a) response of the Czech Republic to a shock in Poland; (b) response of Poland to a shock in the Czech Republic. Source: own calculation (Czech Statistical Office 2021; Polish Statistical Office 2021).

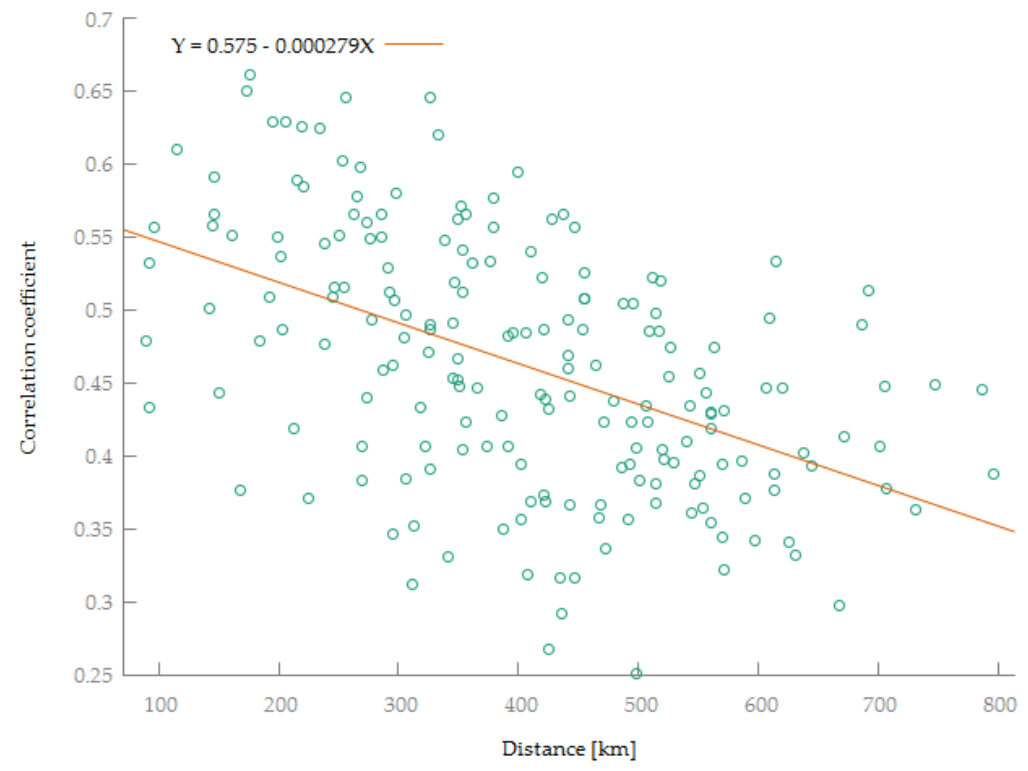

Figure 5. Pearson's linear correlation coefficients between milk prices (logarithm increases) and distance between Czech and Polish regions in the years 2013-2021. Source: own calculation (Czech Statistical Office 2021; Polish Statistical Office 2021).

In the next step, a Granger causality test was performed to examine whether milk prices in Czech regions have predictive power on milk price variation in Polish regions and vice versa (Table 6 ). There is a one-way $(\rightarrow$ ) or two-way $(\leftrightarrow)$ relationship between Czech and Polish milk prices in the short term. It can be concluded that future milk prices in Poland were the Granger cause of milk prices in all Czech regions. In contrast, for only $50 \%$ of the relationship, Czech milk prices were the cause, in the Granger sense, of milk prices in Poland in the analyzed period.

In the light of the Granger causality test, the most exogenous Czech milk prices were in the following regions (Figure 6): Plzeňský kraj, Jihomoravský kraj, Moravskoslezský kraj. In the case of milk prices in Poland, the most exogenous prices in the following voivodeships should be recognized: Mazowieckie, Kujawsko-Pomorskie, Wielkopolskie. The positions of Polish voivodeships seem to be justified mainly by the region's specialization in milk production (statistically significant positive correlation between coefficient F (Granger 
causality test statistics) and milk production of 0.53 . However, in this case, the relationship between the distance of the region and the summed coefficient $F$ was not confirmed for either the Czech Republic or Poland.

Table 6. Direction of dependence based on Granger's causality.

\begin{tabular}{|c|c|c|c|c|c|c|c|c|c|c|c|c|}
\hline Region & STC & JHC & PLK & KVK & LBK & HKK & PAK & VYS & JHM & OLK & ZLK & MSK \\
\hline DOL & $\rightarrow$ & $\leftrightarrow$ & $\leftrightarrow$ & $\leftrightarrow$ & $\rightarrow$ & $\rightarrow$ & $\leftrightarrow$ & $\leftrightarrow$ & $\leftrightarrow$ & $\leftrightarrow$ & $\leftrightarrow$ & $\rightarrow$ \\
\hline $\mathrm{K}-\mathrm{P}$ & $\leftrightarrow$ & $\rightarrow$ & $\leftrightarrow$ & $\leftrightarrow$ & $\rightarrow$ & $\rightarrow$ & $\leftrightarrow$ & $\leftrightarrow$ & $\leftrightarrow$ & $\rightarrow$ & $\leftrightarrow$ & $\leftrightarrow$ \\
\hline LDZ & $\rightarrow$ & $\leftrightarrow$ & $\leftrightarrow$ & $\leftrightarrow$ & $\rightarrow$ & $\rightarrow$ & $\rightarrow$ & $\rightarrow$ & $\rightarrow$ & $\leftrightarrow$ & $\leftrightarrow$ & $\leftrightarrow$ \\
\hline LBL & $\leftrightarrow$ & $\rightarrow$ & $\leftrightarrow$ & $\leftrightarrow$ & $\rightarrow$ & $\rightarrow$ & $\rightarrow$ & $\rightarrow$ & $\leftrightarrow$ & $\leftrightarrow$ & $\leftrightarrow$ & $\leftrightarrow$ \\
\hline LBU & $\rightarrow$ & $\rightarrow$ & $\leftrightarrow$ & $\rightarrow$ & $\rightarrow$ & $\rightarrow$ & $\rightarrow$ & $\rightarrow$ & $\leftrightarrow$ & $\leftrightarrow$ & $\rightarrow$ & $\leftrightarrow$ \\
\hline MLP & $\leftrightarrow$ & $\leftrightarrow$ & $\rightarrow$ & $\leftrightarrow$ & $\rightarrow$ & $\leftrightarrow$ & $\rightarrow$ & $\leftrightarrow$ & $\leftrightarrow$ & $\leftrightarrow$ & $\rightarrow$ & $\rightarrow$ \\
\hline MAZ & $\rightarrow$ & $\rightarrow$ & $\leftrightarrow$ & $\leftrightarrow$ & $\rightarrow$ & $\rightarrow$ & $\rightarrow$ & $\leftrightarrow$ & $\leftrightarrow$ & $\leftrightarrow$ & $\leftrightarrow$ & $\rightarrow$ \\
\hline $\mathrm{OPO}$ & $\leftrightarrow$ & $\leftrightarrow$ & $\rightarrow$ & $\rightarrow$ & $\rightarrow$ & $\rightarrow$ & $\rightarrow$ & $\rightarrow$ & $\leftrightarrow$ & $\rightarrow$ & $\leftrightarrow$ & $\rightarrow$ \\
\hline PKR & $\rightarrow$ & $\rightarrow$ & $\leftrightarrow$ & $\rightarrow$ & $\rightarrow$ & $\rightarrow$ & $\rightarrow$ & $\rightarrow$ & $\leftrightarrow$ & $\rightarrow$ & $\leftrightarrow$ & $\rightarrow$ \\
\hline PDL & $\rightarrow$ & $\rightarrow$ & $\rightarrow$ & $\rightarrow$ & $\rightarrow$ & $\rightarrow$ & $\leftrightarrow$ & $\rightarrow$ & $\rightarrow$ & $\rightarrow$ & $\rightarrow$ & $\leftrightarrow$ \\
\hline POM & $\rightarrow$ & $\leftrightarrow$ & $\leftrightarrow$ & $\leftrightarrow$ & $\rightarrow$ & $\rightarrow$ & $\leftrightarrow$ & $\leftrightarrow$ & $\leftrightarrow$ & $\leftrightarrow$ & $\leftrightarrow$ & $\leftrightarrow$ \\
\hline SL & $\leftrightarrow$ & $\leftrightarrow$ & $\leftrightarrow$ & $\leftrightarrow$ & $\rightarrow$ & $\rightarrow$ & $\rightarrow$ & $\leftrightarrow$ & $\rightarrow$ & $\rightarrow$ & $\rightarrow$ & $\leftrightarrow$ \\
\hline SW & $\rightarrow$ & $\leftrightarrow$ & $\leftrightarrow$ & $\leftrightarrow$ & $\rightarrow$ & $\rightarrow$ & $\rightarrow$ & $\leftrightarrow$ & $\leftrightarrow$ & $\leftrightarrow$ & $\leftrightarrow$ & $\rightarrow$ \\
\hline W-M & $\rightarrow$ & $\rightarrow$ & $\rightarrow$ & $\leftrightarrow$ & $\rightarrow$ & $\rightarrow$ & $\leftrightarrow$ & $\rightarrow$ & $\rightarrow$ & $\rightarrow$ & $\rightarrow$ & $\leftrightarrow$ \\
\hline WLK & $\rightarrow$ & $\leftrightarrow$ & $\leftrightarrow$ & $\leftrightarrow$ & $\rightarrow$ & $\rightarrow$ & $\rightarrow$ & $\rightarrow$ & $\leftrightarrow$ & $\leftrightarrow$ & $\leftrightarrow$ & $\leftrightarrow$ \\
\hline $\mathrm{ZP}$ & $\rightarrow$ & $\leftrightarrow$ & $\leftrightarrow$ & $\leftrightarrow$ & $\leftrightarrow$ & $\leftrightarrow$ & $\leftrightarrow$ & $\leftrightarrow$ & $\leftrightarrow$ & $\leftrightarrow$ & $\rightarrow$ & $\leftrightarrow$ \\
\hline
\end{tabular}

Source: own calculation (Czech Statistical Office 2021; Polish Statistical Office 2021).

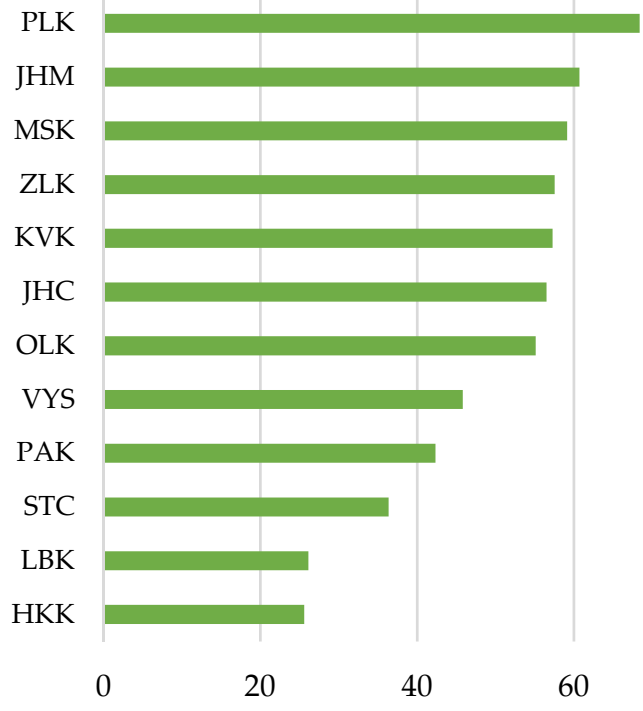

(a)

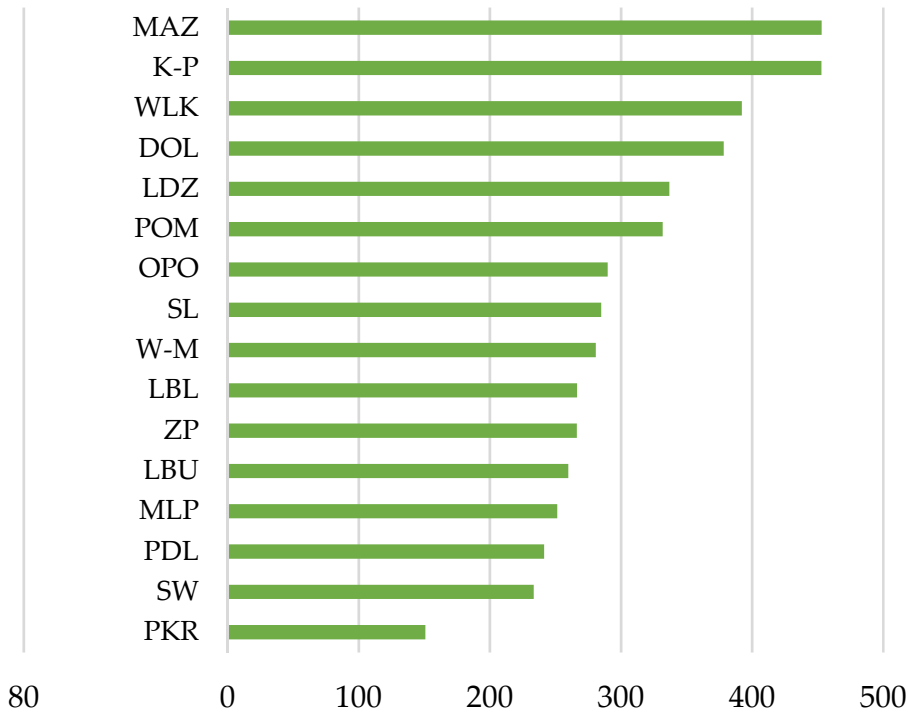

(b)

Figure 6. Summary of Granger causality testing results between milk price series in the Czech Republic and Poland: (a) Czech regions, (b) Polish regions (sum of $F$ test statistics). Source: Source: own calculation (Czech Statistical Office 2021; Polish Statistical Office 2021).

\subsection{Dairy Products Market Integration of Poland and the Czech Republic}

The final part of the analysis focuses on dairy products. Since the butter and SMP price series were integrated at order I(1), the Johansen cointegration test was performed in the next step. The results of the cointegration test are summarized in Table 7. Note that the statistical values of the tests are greater than their critical values at $p=0.05$ for SMP prices only. This means that there is a long-run relationship between the price of SMP in the Czech Republic and the price of SMP in Poland. Thus, the results are consistent with the findings of Domagała (2020), who analyzed price relationships over the period 2004-2016. In contrast, there is no long-run relationship between butter prices in these countries. 
Table 7. Cointegration testing results and selected VAR/VECM statistics for the Czech Republic and Poland's dairy products price series.

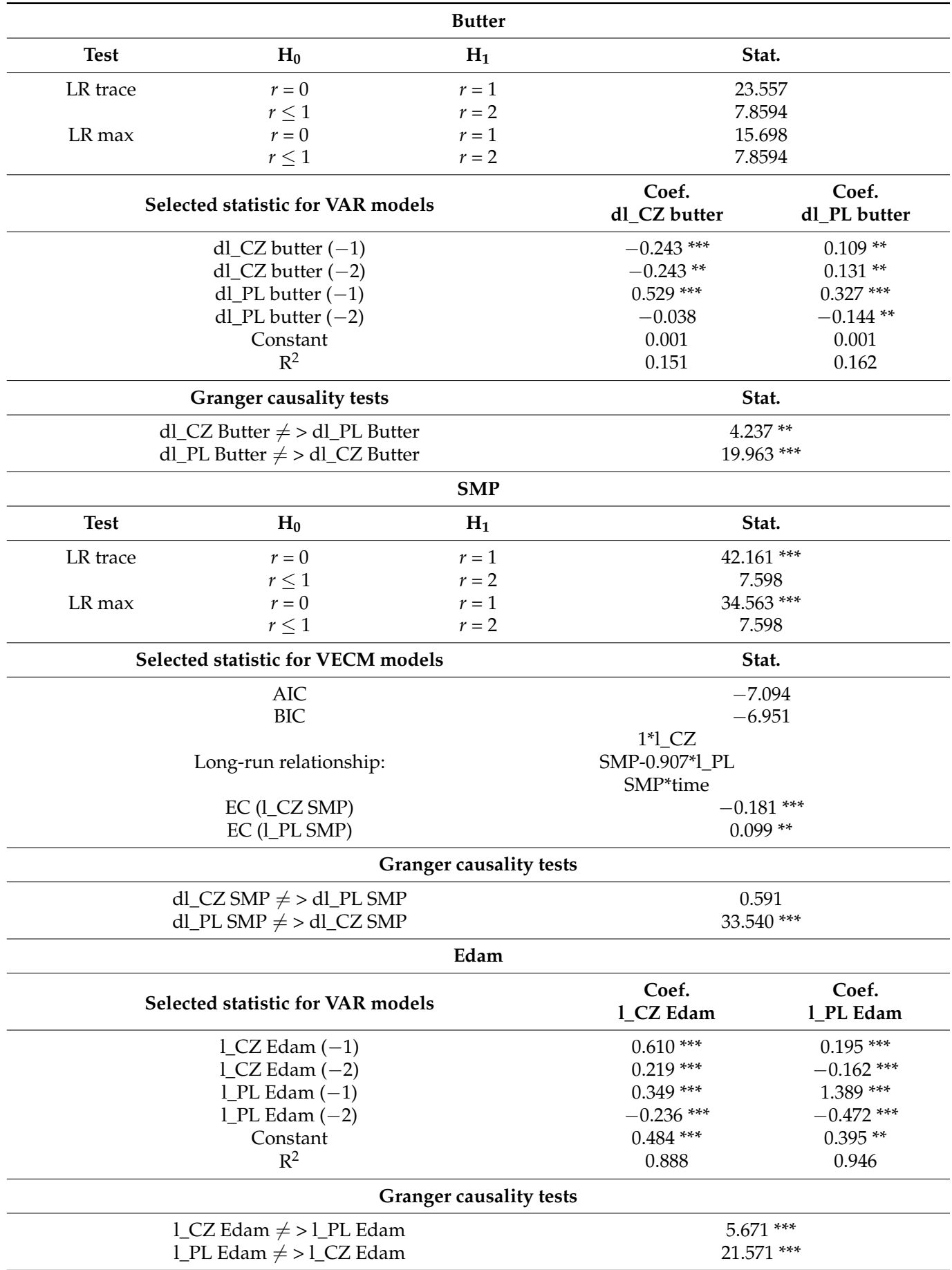

${ }^{* *} p<0.05,{ }^{* * *} p<0.01$. Note: $\mathrm{r}=$ rank; 1 = price logarithm; dl = first differences of price logarithms; $1 \times 1 \_\mathrm{CZ}$ SMP-0.907 $\times 1 \_P L S M P \times$ time which indicates that, in the long-run relationship, 1\% increase/decrease in SMP prices in the Czech Republic is reflected by a $0.907 \%$ increase/decrease in SMP prices in Poland; EC (1_CZ SMP) = error correction component for Czech SMP prices; EC (1_PL Raw milk) = error correction component for Polish SMP prices; dl_CZ butter $\neq>$ dl_PL butter means whether future butter prices in the Czech Republic are the cause, in the sense of Granger, of future butter prices in Poland; dl_PL butter $\neq>$ dl_CZ butter means whether future butter prices in Poland are the cause, in the sense of Granger, of future butter prices in the Czech Republic the same applies to SMP and EDAM cheese. Source: own calculation (CLAL.IT 2021). 
Since there was one cointegrating rank in the SMP price relationship, the VECM model was used. The coefficient in the long-run relationship in the model with a limited trend and an unlimited constant is 0.91 ; this indicates that, in the long-run relationship, a $1 \%$ increase/decrease in SMP prices in the Czech Republic is reflected by $0.91 \%$ increase/decrease in SMP prices in Poland. Long-run relationship coefficients close to 1 reflect the validity of LOP in the spatial markets analyzed. Both Czech SMP prices are an exogenous variable for Polish SMP prices, and Polish SMP prices for Czech SMP prices, as the coefficients with deviations from long-run equilibrium (EC) present in the equation of Czech and Polish SMP prices are statistically significant. Imbalances due to shocks in the price system are corrected during the month by $18.1 \%$ through the Czech Republic's response, and by $9.9 \%$ through the Polish price response. Moreover, in the light of the Granger test performed, it can be concluded that future prices of SMP in Poland are a cause, in the Granger sense, of future SMP prices in the Czech Republic. Thus, this trend continues as confirmed by Domagała's (2020) studies. Moreover, the reaction of Czech SMP prices to Polish SMP prices and vice versa is positive and stable over 5 months (Figure 7).

Since there was no cointegration between the butter price series, a VAR model was estimated. According to the AIC, the minimum lag length in the VAR model was $p=3$. Since all the endogenous variables of this study are integrated on the first order that is not cointegrated, the VAR $(p-1)$ model is estimated, so the lag length is $2(p-1=2)$. The R2 value for each VAR model indicates that the overall quality of fit is not satisfactory. For example, about $15 \%$ of the variability in Czech butter prices can be explained by Czech and Polish butter prices. Regarding the short-run butter price relationship, there is a two-way result given by the Granger causality test. This means that future butter prices in the Czech Republic are a cause, in the Granger sense, of future butter prices in Poland, and vice versa. Thus, the results of Roman (2018) and Domagała (2021), who examined the price linkage over the period 2012-2016, are confirmed. It should be noted that prior to this year, only butter prices in Poland influenced future butter prices in the Czech Republic. Further evidence of a short-run relationship between butter prices in the analyzed countries can be inferred from the IRF test. The reaction of butter prices in the Czech Republic to butter prices in Poland and vice versa is positive. The impact change occurs after month 2 for Czech butter prices and after month 4 for Polish butter prices.

In the case of cheese, the time series were integrated at order $\mathrm{I}(0)$; therefore, no cointegration tests were performed, only the VAR model was estimated. The R2 value for each VAR model indicates that the overall quality of fit is satisfactory. For example, about $89 \%$ of the variability in Czech cheese prices can be explained by Czech and Polish Edam prices. As for the short-run butter price relationship, we have a two-way result here as well, following the Granger causality test. This means that future cheese prices in the Czech Republic are a cause, in the Granger sense, of future cheese prices in Poland, and vice versa. In the case of the results from the impulse response analysis, the response of cheese prices in the Czech Republic to cheese prices in Poland, and vice versa, is positive and long-lasting. 


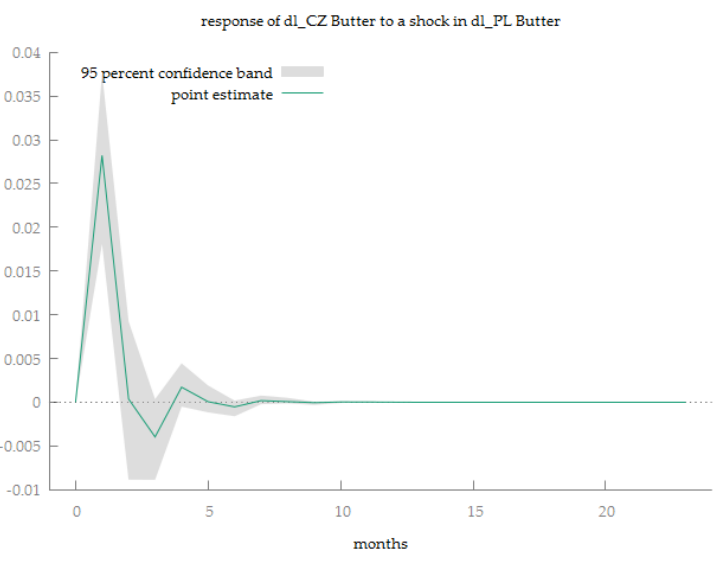

(a)

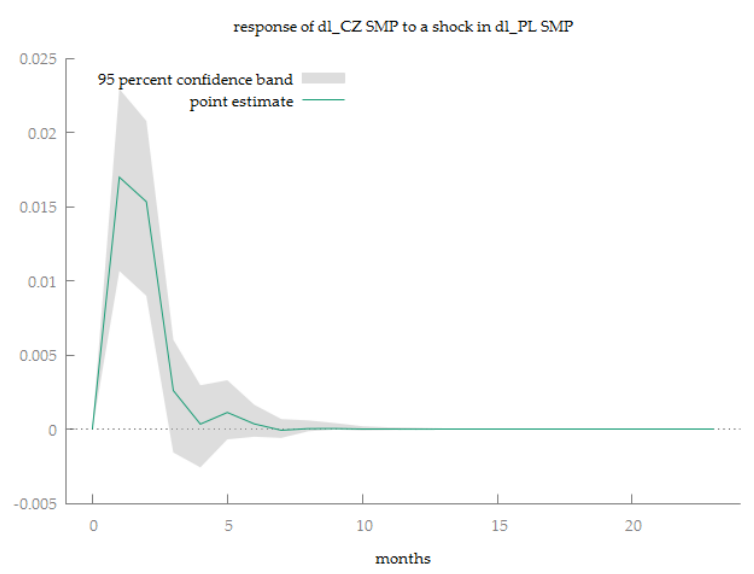

(c)

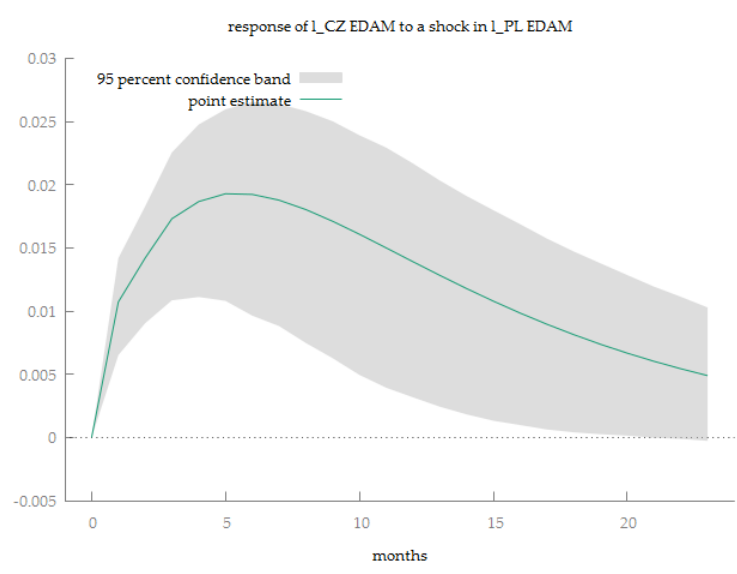

(e)

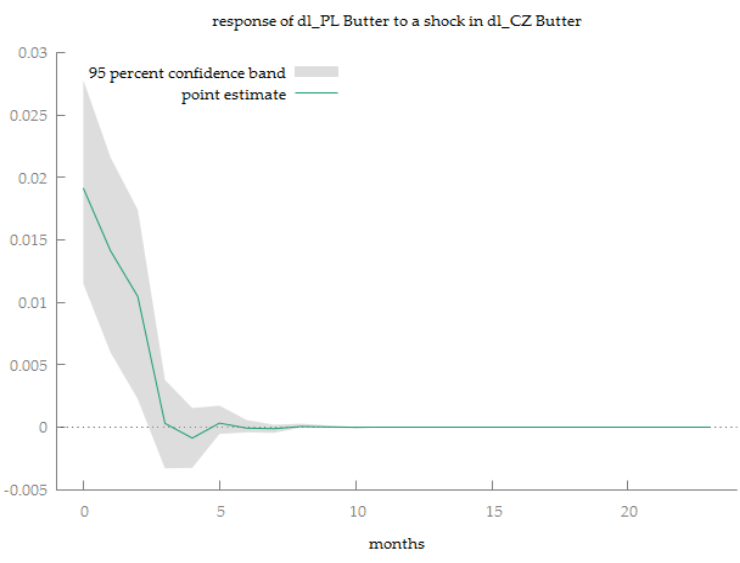

(b)

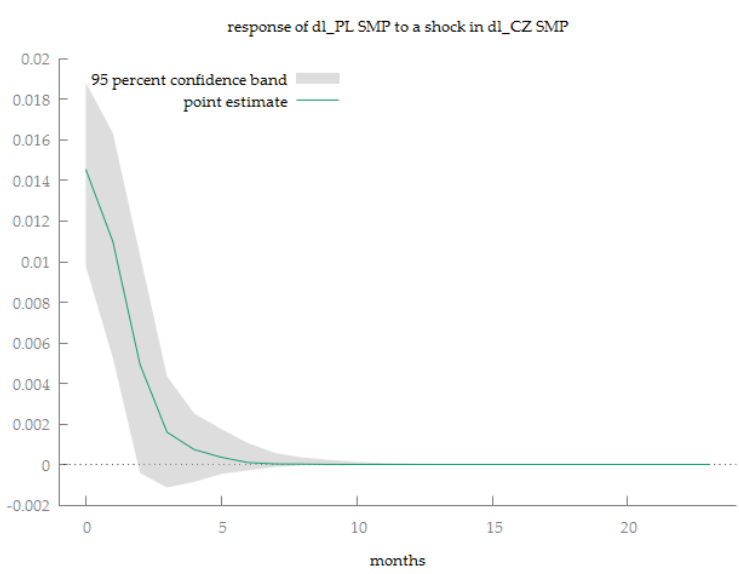

(d)

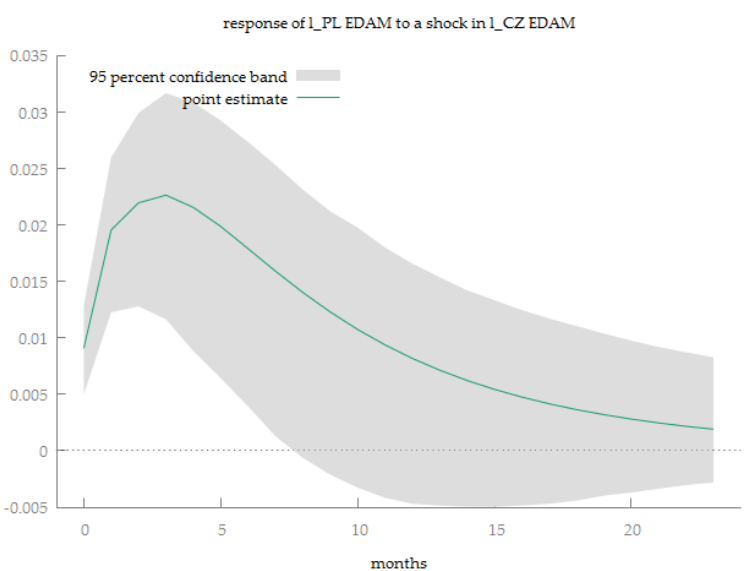

(f)

Figure 7. Impulse response function between butter prices: (a) response of Czech Republic to a shock in Poland; (b) response of Poland to a shock in the Czech Republic; SMP prices: (c) response of Czech Republic to a shock in Poland; (d) response of Poland to a shock in the Czech Republic; Edam prices: (e) response of Czech Republic to a shock in Poland; (f) response of Poland to a shock in the Czech Republic. Source: own calculations (CLAL.IT 2021).

\section{Conclusions}

The integration of markets and the equalization of prices in EU countries is one of the main objectives of the Common Agricultural Policy. This paper evaluates the processes of spatial integration in the market of milk and dairy products between Poland and the 
Czech Republic. Among other things, the countries share a long history of trade in dairy products, proximity, and the same moment of accession to the EU.

To achieve the aim of the paper, methods of evaluating spatial integration processes based on trade flows and prices were used. The analysis was conducted for a 21-year period at the national level and a 9-year period at the regional level. Four markets were selected for analysis: raw milk, butter, SMP, and Edam cheese.

Based on the research conducted, it can be noted that: (1) on the basis of the results of trade flows, one would have to conclude that the Czech Republic and Poland are characterized by a long range of linkages, which is a strong indication of the integration of these two markets for all analyzed products; (2) based on the analysis of price differences, in most cases, the prices of dairy products in the Czech Republic were higher than the prices of these products in Poland; the smallest differences were found in the prices of SMP (on average $-0.6 \%$ ), and the highest differences were found in the prices of milk (on average $-2.0 \%$ ); (3) a long-run price relationship between the Czech Republic and Poland was confirmed by the Johansen cointegration test for milk and SMP only; (4) in the light of the Granger test performed for milk, butter, and Edam cheese prices, there was a two-way causality, while in the case of SMP prices, only future SMP prices in Poland were the cause, in the Granger sense, of future SMP prices in the Czech Republic; (5) despite the long-run relationship of milk prices at the national level, in the case of regional analysis, for only half of the analyzed pairs of Czech and Polish regions was such a relationship also long-run; in the case of the Czech Republic, these were the regions closest to Poland, which, thus, confirmed the importance of distance. In the case of Poland, the highest number of long-run linkages was obtained by regions specializing in milk production; (6) the results of the study confirmed that the factors influencing the spatial price relationships between the Czech Republic and Poland are: strong trade ties, a common moment of accession to the EU, a close distance between markets, and region specialization.

Despite meeting the purpose of the article, it should also be noted that our study is not without limitations. In such analyses, the length of the time series matters; an analysis using weekly data of product prices would even more effectively estimate linkages. Despite some limitations, our study provides an interesting starting point for future research. The methodology used in this article can be replicated and evaluated for the phenomenon being studied in another few years. Another suggestion would be to use nonlinear models to assess spatial integration processes between the two markets, as well as regional analysis for other separate markets.

Author Contributions: Conceptualization, M.R. and Z.Ž.K.; methodology, M.R.; software, M.R.; validation, M.R.; formal analysis, M.R.; investigation, M.R. and Z.Ž.K.; resources, M.R. and Z.Ž.K.; data curation, M.R. and Z.Ž.K.; writing—original draft preparation, M.R. and Z.Ž.K.; writingreview and editing, M.R. and Z.Ž.K.; visualization, M.R.; supervision, M.R.; project administration, M.R.; funding acquisition, M.R. All authors have read and agreed to the published version of the manuscript.

Funding: This research was funded by POLISH NATIONAL AGENCY FOR ACADEMIC EXCHANGE grant number PPN/BIL/2020/1/00221.

Institutional Review Board Statement: Not applicable.

Informed Consent Statement: Not applicable.

Data Availability Statement: Not applicable.

Conflicts of Interest: The authors declare no conflict of interest. 


\section{Appendix A}

Table A1. Unit root testing results.

\begin{tabular}{|c|c|c|c|c|c|}
\hline \multirow[b]{2}{*}{ Product/Region } & \multicolumn{2}{|c|}{ Price Logarithms } & \multicolumn{2}{|c|}{ First Price Differences } & \multirow[b]{2}{*}{ Decision } \\
\hline & $\begin{array}{c}\text { ADF-GLS } \\
\text { Stat. }\end{array}$ & $\begin{array}{c}\text { Phillips-Perron } \\
\text { Z Stat }\end{array}$ & $\begin{array}{c}\text { ADF-GLS } \\
\text { Stat. }\end{array}$ & $\begin{array}{c}\text { Phillips-Perron } \\
\text { Z Stat }\end{array}$ & \\
\hline \multicolumn{6}{|c|}{ 2001-2021 } \\
\hline $\mathrm{CZ}$ raw milk & -1.258 & $-2.668 *$ & $-4.707 * * *$ & $-6.948^{* * *}$ & $\mathrm{I}(1)$ \\
\hline PL raw milk & -0.874 & -1.856 & $-6.733^{* * *}$ & $-8.132 * * *$ & $\mathrm{I}(1)$ \\
\hline CZ butter & $-1.669 *$ & $-2.597 *$ & $-6.123^{* * *}$ & $-17.077^{* * *}$ & $\mathrm{I}(1)$ \\
\hline PL butter & $-1.629 *$ & -2.318 & $-8.458 * * *$ & $-10.577 * * *$ & $\mathrm{I}(1)$ \\
\hline CZ SMP & $-1.877 *$ & -2.281 & $-4.699 * * *$ & $-14.627^{* * *}$ & $\mathrm{I}(1)$ \\
\hline PL SMP & $-1.950 *$ & -2.408 & $-3.088^{* * *}$ & $-8.572 * * *$ & $\mathrm{I}(1)$ \\
\hline CZ Edam & $-0.938 *$ & $-3.215^{* *}$ & $-2.936^{* * *}$ & $-18.623^{* * *}$ & $\mathrm{I}(0)$ \\
\hline PL Edam & $-3.807^{* * *}$ & $-3.141^{* *}$ & $-3.283^{* * *}$ & $-9.515^{* * *}$ & $\mathrm{I}(0)$ \\
\hline \multicolumn{6}{|c|}{ 2013-2021 } \\
\hline STC & -1.721 & -1.851 & $-4.021^{* * *}$ & $-4.203^{* * *}$ & $\mathrm{I}(1)$ \\
\hline $\mathrm{JHC}$ & -1.991 & -1.972 & $-4.359 * * *$ & $-4.513^{* * *}$ & $\mathrm{I}(1)$ \\
\hline PLK & -2.159 & -1.974 & $-3.619 * * *$ & $-4.695^{* * *}$ & $\mathrm{I}(1)$ \\
\hline KVK & -1.753 & -2.174 & $-3.686^{* * *}$ & $-5.081 * * *$ & $\mathrm{I}(1)$ \\
\hline LBK & -1.696 & -1.745 & $-4.419 * * *$ & $-6.754 * * *$ & $\mathrm{I}(1)$ \\
\hline HKK & -1.795 & -1.814 & $-3.327 * * *$ & $-5.301^{* * *}$ & $\mathrm{I}(1)$ \\
\hline PAK & -1.659 & -1.854 & $-3.765 * * *$ & $-4.725^{* * *}$ & $\mathrm{I}(1)$ \\
\hline VYS & -1.952 & -1.906 & $-3.228 * * *$ & $-4.176^{* * *}$ & $\mathrm{I}(1)$ \\
\hline JHM & -1.588 & -1.868 & $-3.629 * * *$ & $-4.340^{* * *}$ & $\mathrm{I}(1)$ \\
\hline OLK & -1.649 & -1.933 & $-4.039 * * *$ & $-4.308^{* * *}$ & $\mathrm{I}(1)$ \\
\hline ZLK & -1.752 & -1.846 & $-3.221 * * *$ & $-4.473^{* * *}$ & $\mathrm{I}(1)$ \\
\hline MSK & -2.043 & -1.820 & $-3.020 * * *$ & $-5.195^{* * *}$ & $\mathrm{I}(1)$ \\
\hline DOL & -1.068 & -1.904 & $-3.952 * * *$ & $-5.041^{* * *}$ & $\mathrm{I}(1)$ \\
\hline $\mathrm{K}-\mathrm{P}$ & -0.960 & -1.636 & $-3.726^{* * *}$ & $-4.395^{* * *}$ & $\mathrm{I}(1)$ \\
\hline LDZ & -1.100 & -1.634 & $-4.687^{* * *}$ & $-4.861 * * *$ & $\mathrm{I}(1)$ \\
\hline LBL & -1.456 & -1.900 & $-4.735^{* * *}$ & $-6.669 * * *$ & $\mathrm{I}(1)$ \\
\hline LBU & -1.381 & -1.947 & $-4.259 * * *$ & $-8.449^{* * *}$ & $\mathrm{I}(1)$ \\
\hline MLP & -1.284 & -1.617 & $-2.836^{* * *}$ & $-7.068^{* * *}$ & $\mathrm{I}(1)$ \\
\hline MAZ & -1.247 & -1.821 & $-4.152 * * *$ & $-6.020 * * *$ & $\mathrm{I}(1)$ \\
\hline $\mathrm{OPO}$ & -1.030 & -1.874 & $-4.829 * * *$ & $-5.010 * * *$ & $\mathrm{I}(1)$ \\
\hline PKR & -1.201 & -1.706 & $-3.836^{* * *}$ & $-9.154 * * *$ & $\mathrm{I}(1)$ \\
\hline PDL & -1.906 & -1.915 & $-5.083^{* * *}$ & $-6.490 * * *$ & $\mathrm{I}(1)$ \\
\hline POM & -1.427 & -1.969 & $-4.318^{* * *}$ & $-5.247^{* * *}$ & $\mathrm{I}(1)$ \\
\hline SL & -1.549 & -1.995 & $-4.140 * * *$ & $-5.487 * * *$ & $\mathrm{I}(1)$ \\
\hline SW & -1.424 & -1.807 & $-4.197^{* * *}$ & $-6.334^{* * *}$ & $\mathrm{I}(1)$ \\
\hline W-M & -1.387 & -1.975 & $-4.849 * * *$ & $-5.983^{* * *}$ & $\mathrm{I}(1)$ \\
\hline WLK & -1.305 & -1.787 & $-5.028 * * *$ & $-5.153^{* * *}$ & $\mathrm{I}(1)$ \\
\hline Z-P & -1.744 & -2.009 & $-3.900 * * *$ & $-6.527^{* * *}$ & $\mathrm{I}(1)$ \\
\hline
\end{tabular}

${ }^{*} p<0.1,{ }^{* *} p<0.05,{ }^{* * *} p<0.01$. Source: own calculations.

Table A2. Cointegration results.

\begin{tabular}{|c|c|c|c|c|c|c|c|c|c|c|c|c|c|}
\hline Region & $\begin{array}{c}\mathrm{H}_{0} \text { : } \\
\text { Rank }\end{array}$ & 1_STC & 1_JHC & 1_PLK & 1_KVK & 1_LBK & 1_HKK & 1_PAK & 1_VYS & 1_JHM & 1_OLK & 1_ZLK & 1_MSK \\
\hline \multirow{2}{*}{ 1_DOL } & 0 & $\begin{array}{c}22.304 \\
{[0.1312]}\end{array}$ & $\begin{array}{c}23.532 \\
{[0.0944]}\end{array}$ & $\begin{array}{c}17.194 \\
{[0.4086]}\end{array}$ & $\begin{array}{c}21.391 \\
{[0.1654]}\end{array}$ & $\begin{array}{c}24.559 \\
{[0.0707]}\end{array}$ & $\begin{array}{c}22.921 \\
{[0.1115]}\end{array}$ & $\begin{array}{c}20.969 \\
{[0.1834]}\end{array}$ & $\begin{array}{c}22.712 \\
{[0.1178]}\end{array}$ & $\begin{array}{c}23.709 \\
{[0.0899]}\end{array}$ & $\begin{array}{c}21.748 \\
{[0.1513]}\end{array}$ & $\begin{array}{c}14.224 \\
{[0.6442]}\end{array}$ & $\begin{array}{c}20.214 \\
{[0.2192]}\end{array}$ \\
\hline & 1 & $\begin{array}{c}5.673 \\
{[0.5126]}\end{array}$ & $\begin{array}{c}9.696 \\
{[0.1444]}\end{array}$ & $\begin{array}{c}6.391 \\
{[0.4230]}\end{array}$ & $\begin{array}{c}9.323 \\
{[0.1650]}\end{array}$ & $\begin{array}{c}5.549 \\
{[0.5289]}\end{array}$ & $\begin{array}{c}6.940 \\
{[0.3609]}\end{array}$ & $\begin{array}{c}5.022 \\
{[0.6002]}\end{array}$ & $\begin{array}{c}6.834 \\
{[0.3724]}\end{array}$ & $\begin{array}{c}7.083 \\
{[0.3458]}\end{array}$ & $\begin{array}{c}8.899 \\
{[0.1916]}\end{array}$ & & $\begin{array}{c}4.9325 \\
{[0.6126]}\end{array}$ \\
\hline \multirow{2}{*}{ 1_K-P } & 0 & $\begin{array}{c}22.762 \\
{[0.1163]}\end{array}$ & $\begin{array}{c}24.974 \\
{[0.0626]}\end{array}$ & $\begin{array}{c}20.498 \\
{[0.2051]}\end{array}$ & $\begin{array}{c}22.732 \\
{[0.1172]}\end{array}$ & $\begin{array}{c}29.464 \\
{[0.0151]}\end{array}$ & $\begin{array}{c}25.272 \\
{[0.0574]}\end{array}$ & $\begin{array}{c}29.100 \\
{[0.0171]}\end{array}$ & $\begin{array}{c}22.201 \\
{[0.1347]}\end{array}$ & $\begin{array}{c}30.090 \\
{[0.0122]}\end{array}$ & & $\begin{array}{c}17.168 \\
{[0.4105]}\end{array}$ & $\begin{array}{c}23.733 \\
{[0.0893]}\end{array}$ \\
\hline & 1 & $\begin{array}{c}8.716 \\
{[0.2040]}\end{array}$ & $\begin{array}{c}8.351 \\
{[0.2309]}\end{array}$ & $\begin{array}{c}7.845 \\
{[0.2726]}\end{array}$ & $\begin{array}{c}7.742 \\
{[0.2818]}\end{array}$ & $\begin{array}{c}6.617 \\
{[0.3966]}\end{array}$ & $\begin{array}{c}6.607 \\
{[0.3977]}\end{array}$ & $\begin{array}{c}7.997 \\
{[0.2595]}\end{array}$ & $\begin{array}{c}8.462 \\
{[0.2224]}\end{array}$ & $\begin{array}{c}7.574 \\
{[0.2972]}\end{array}$ & $\begin{array}{c}9.073 \\
{[0.1803]}\end{array}$ & $\begin{array}{c}5.891 \\
{[0.4844]}\end{array}$ & $\begin{array}{c}7.004 \\
{[0.3541]}\end{array}$ \\
\hline \multirow{2}{*}{ 1_LDZ } & 0 & $\begin{array}{c}20.108 \\
{[0.2246]}\end{array}$ & $\begin{array}{c}23.661 \\
{[0.0911]}\end{array}$ & $\begin{array}{c}16.820 \\
{[0.4366]}\end{array}$ & $\begin{array}{c}14.211 \\
{[0.6453]}\end{array}$ & $\begin{array}{c}27.491 \\
{[0.0289]}\end{array}$ & $\begin{array}{c}21.358 \\
{[0.1668]}\end{array}$ & $\begin{array}{c}25.515 \\
{[0.0534]}\end{array}$ & $\begin{array}{c}20.139 \\
{[0.2230]}\end{array}$ & $\begin{array}{c}23.290 \\
{[0.1009]}\end{array}$ & $\begin{array}{c}20.454 \\
{[0.2073]}\end{array}$ & $\begin{array}{c}13.832 \\
{[0.6755]}\end{array}$ & $\begin{array}{c}30.035 \\
{[0.0125]}\end{array}$ \\
\hline & 1 & $\begin{array}{c}8.521 \\
{[0.2180]}\end{array}$ & $\begin{array}{c}10.35 \\
{[0.1133]}\end{array}$ & $\begin{array}{c}7.408 \\
{[0.3130]}\end{array}$ & $\begin{array}{c}4.851 \\
{[0.6238]}\end{array}$ & $\begin{array}{c}7.896 \\
{[0.2682]}\end{array}$ & $\begin{array}{c}5.376 \\
{[0.5520]}\end{array}$ & $\begin{array}{c}6.269 \\
{[0.4375]}\end{array}$ & $\begin{array}{c}9.742 \\
{[0.1420]}\end{array}$ & $\begin{array}{c}10.20 \\
{[0.1196]}\end{array}$ & $\begin{array}{c}8.429 \\
{[0.2249]}\end{array}$ & $\begin{array}{c}4.967 \\
{[0.6079]}\end{array}$ & $\begin{array}{c}9.441 \\
{[0.1583]}\end{array}$ \\
\hline
\end{tabular}


Table A2. Cont.

\begin{tabular}{|c|c|c|c|c|c|c|c|c|c|c|c|c|c|}
\hline Region & $\begin{array}{c}\mathrm{H}_{0} \text { : } \\
\text { Rank }\end{array}$ & STC & 1_JHC & 1_PLK & 1_KVK & 1_LBK & 1_HKK & 1_PAK & 1_VYS & 1_JHM & 1_OLK & 1_ZLK & 1_MSK \\
\hline \multirow{2}{*}{ 1_LBL } & 0 & $\begin{array}{c}33.71 \\
{[0.0033]}\end{array}$ & $\begin{array}{c}33.59 \\
{[0.0035]}\end{array}$ & $\begin{array}{c}22.928 \\
{[0.1113]}\end{array}$ & $\begin{array}{c}21.276 \\
{[0.1702]}\end{array}$ & $\begin{array}{c}43.052 \\
{[0.0001]}\end{array}$ & $\begin{array}{c}36.389 \\
{[0.0012]}\end{array}$ & $\begin{array}{c}36.424 \\
{[0.0012]}\end{array}$ & $\begin{array}{c}23.310 \\
{[0.1003]}\end{array}$ & $\begin{array}{c}24.551 \\
{[0.0708]}\end{array}$ & & $\begin{array}{c}19.643 \\
{[0.2493]}\end{array}$ & $\begin{array}{c}41.542 \\
{[0.0002]}\end{array}$ \\
\hline & 1 & $\begin{array}{c}9.767 \\
{[0.1407]}\end{array}$ & $\begin{array}{c}10.744 \\
{[0.0978]}\end{array}$ & $\begin{array}{c}6.782 \\
{[0.3781]} \\
\end{array}$ & $\begin{array}{c}8.921 \\
{[0.1901]} \\
\end{array}$ & $\begin{array}{c}8.123 \\
{[0.2490]} \\
\end{array}$ & $\begin{array}{c}9.188 \\
{[0.1732]}\end{array}$ & $\begin{array}{c}9.348 \\
{[0.1636]}\end{array}$ & $\begin{array}{c}8.854 \\
{[0.1945]} \\
\end{array}$ & $\begin{array}{c}7.941 \\
{[0.2643]} \\
\end{array}$ & $\begin{array}{c}11.609 \\
{[0.0699]}\end{array}$ & $\begin{array}{c}6.0223 \\
{[0.4680]}\end{array}$ & $\begin{array}{c}10.331 \\
{[0.1143]}\end{array}$ \\
\hline \multirow{2}{*}{ 1_LBU } & 0 & $\begin{array}{c}24.199 \\
{[0.0783]}\end{array}$ & $\begin{array}{c}16.048 \\
{[0.4967]}\end{array}$ & $\begin{array}{c}17.027 \\
{[0.4210]}\end{array}$ & $\begin{array}{c}14.971 \\
{[0.5836]}\end{array}$ & $\begin{array}{c}31.322 \\
{[0.0080]}\end{array}$ & $\begin{array}{c}11.251 \\
{[0.8562]}\end{array}$ & $\begin{array}{c}13.784 \\
{[0.6793]}\end{array}$ & $\begin{array}{c}14.427 \\
{[0.6278]}\end{array}$ & $\begin{array}{c}16.113 \\
{[0.4916]}\end{array}$ & $\begin{array}{c}14.562 \\
{[0.6169]} \\
\end{array}$ & $\begin{array}{c}14.412 \\
{[0.6290]}\end{array}$ & $\begin{array}{c}19.842 \\
{[0.2385]}\end{array}$ \\
\hline & 1 & $\begin{array}{c}9.045 \\
{[0.1820]}\end{array}$ & $\begin{array}{c}7.765 \\
{[0.2797]}\end{array}$ & $\begin{array}{c}8.088 \\
{[0.2519]} \\
\end{array}$ & $\begin{array}{c}6.052 \\
{[0.4642]} \\
\end{array}$ & $\begin{array}{c}8.242 \\
{[0.2394]} \\
\end{array}$ & $\begin{array}{c}4.465 \\
{[0.6773]}\end{array}$ & $\begin{array}{c}5.231 \\
{[0.5717]}\end{array}$ & $\begin{array}{c}5.544 \\
{[0.5296]}\end{array}$ & $\begin{array}{c}5.226 \\
{[0.5723]} \\
\end{array}$ & $\begin{array}{c}5.591 \\
{[0.5234]}\end{array}$ & $\begin{array}{c}7.007 \\
{[0.3538]}\end{array}$ & $\begin{array}{c}6.871 \\
{[0.3684]}\end{array}$ \\
\hline \multirow{2}{*}{ 1_MLP } & 0 & $\begin{array}{c}17.178 \\
{[0.4098]}\end{array}$ & $\begin{array}{c}23.692 \\
{[0.0903]}\end{array}$ & $\begin{array}{l}27.930 \\
{[0.0251]}\end{array}$ & $\begin{array}{c}22.927 \\
{[0.1113]}\end{array}$ & $\begin{array}{c}17.505 \\
{[0.3859]}\end{array}$ & $\begin{array}{c}17.616 \\
{[0.3780]}\end{array}$ & $\begin{array}{c}18.268 \\
{[0.3331]} \\
\end{array}$ & $\begin{array}{c}19.318 \\
{[0.2677]}\end{array}$ & $\begin{array}{c}15.779 \\
{[0.5182]}\end{array}$ & & $\begin{array}{c}15.535 \\
{[0.5379]}\end{array}$ & $\begin{array}{c}28.159 \\
{[0.0233]}\end{array}$ \\
\hline & 1 & $\begin{array}{c}6.777 \\
{[0.3787]} \\
\end{array}$ & $\begin{array}{c}9.269 \\
{[0.1682]}\end{array}$ & $\begin{array}{c}10.783 \\
{[0.0963]}\end{array}$ & $\begin{array}{c}6.965 \\
{[0.3583]}\end{array}$ & $\begin{array}{c}6.299 \\
{[0.4339]}\end{array}$ & $\begin{array}{c}8.491 \\
{[0.2203]}\end{array}$ & $\begin{array}{c}8.557 \\
{[0.2154]}\end{array}$ & $\begin{array}{c}5.960 \\
{[0.4757]} \\
\end{array}$ & $\begin{array}{c}6.748 \\
{[0.3819]}\end{array}$ & $\begin{array}{c}8.426 \\
{[0.2251]}\end{array}$ & $\begin{array}{c}6.145 \\
{[0.4527]}\end{array}$ & $\begin{array}{c}9.569 \\
{[0.1511]}\end{array}$ \\
\hline \multirow{2}{*}{ 1_MAZ } & 0 & $\begin{array}{c}28.888 \\
{[0.0183]}\end{array}$ & $\begin{array}{c}17.855 \\
{[0.3612]}\end{array}$ & $\begin{array}{c}19.509 \\
{[0.2569]}\end{array}$ & $\begin{array}{c}16.042 \\
{[0.4972]}\end{array}$ & $\begin{array}{c}22.233 \\
{[0.1336]}\end{array}$ & $\begin{array}{c}25.902 \\
{[0.0475]}\end{array}$ & $\begin{array}{c}25.031 \\
{[0.0616]} \\
\end{array}$ & $\begin{array}{c}16.997 \\
{[0.4232]}\end{array}$ & $\begin{array}{c}17.928 \\
{[0.3561]}\end{array}$ & $\begin{array}{c}15.898 \\
{[0.5087]}\end{array}$ & & \\
\hline & 1 & $\begin{array}{c}10.674 \\
{[0.1004]} \\
\end{array}$ & $\begin{array}{c}6.479 \\
{[0.4126]}\end{array}$ & $\begin{array}{c}6.040 \\
{[0.4657]}\end{array}$ & $\begin{array}{c}6.621 \\
{[0.3962]}\end{array}$ & $\begin{array}{c}4.595 \\
{[0.6593]}\end{array}$ & $\begin{array}{c}5.372 \\
{[0.5526]}\end{array}$ & $\begin{array}{c}6.326 \\
{[0.4306]}\end{array}$ & $\begin{array}{c}5.934 \\
{[0.4790]}\end{array}$ & $\begin{array}{c}6.344 \\
{[0.4285]}\end{array}$ & $\begin{array}{c}6.589 \\
{[0.3998]}\end{array}$ & $\begin{array}{c}5.236 \\
{[0.5710]}\end{array}$ & $\begin{array}{c}5.292 \\
{[0.5634]}\end{array}$ \\
\hline \multirow{2}{*}{ 1_OPO } & 0 & $\begin{array}{c}23.178 \\
{[0.1040]}\end{array}$ & $\begin{array}{c}28.070 \\
{[0.0240]}\end{array}$ & $\begin{array}{c}29.701 \\
{[0.0140]}\end{array}$ & $\begin{array}{c}21.595 \\
{[0.1572]}\end{array}$ & $\begin{array}{c}30.632 \\
{[0.0101]}\end{array}$ & $\begin{array}{c}25.838 \\
{[0.0484]}\end{array}$ & $\begin{array}{c}25.213 \\
{[0.0584]}\end{array}$ & $\begin{array}{c}23.874 \\
{[0.0858]}\end{array}$ & & & & $\begin{array}{c}31.558 \\
{[0.0073]}\end{array}$ \\
\hline & 1 & $\begin{array}{c}7.837 \\
{[0.2734]}\end{array}$ & $\begin{array}{c}10.232 \\
{[0.1186]}\end{array}$ & $\begin{array}{c}9.565 \\
{[0.1514]}\end{array}$ & $\begin{array}{c}8.923 \\
{[0.1899]}\end{array}$ & $\begin{array}{c}6.733 \\
{[0.3836]}\end{array}$ & $\begin{array}{c}7.777 \\
{[0.2787]}\end{array}$ & $\begin{array}{c}7.511 \\
{[0.3031]}\end{array}$ & $\begin{array}{c}8.502 \\
{[0.2194]}\end{array}$ & $\begin{array}{c}8.151 \\
{[0.2468]}\end{array}$ & $\begin{array}{c}9.406 \\
{[0.1603]}\end{array}$ & $\begin{array}{c}6.350 \\
{[0.4278]}\end{array}$ & $\begin{array}{c}8.604 \\
{[0.2120]}\end{array}$ \\
\hline \multirow{2}{*}{ 1_PKR } & 0 & $\begin{array}{c}26.385 \\
{[0.0410]}\end{array}$ & $\begin{array}{c}18.901 \\
{[0.2926]}\end{array}$ & $\begin{array}{c}19.851 \\
{[0.2380]}\end{array}$ & $\begin{array}{c}33.371 \\
{[0.0038]}\end{array}$ & $\begin{array}{c}29.026 \\
{[0.0175]}\end{array}$ & $\begin{array}{c}29.363 \\
{[0.0156]}\end{array}$ & & $\begin{array}{c}28.023 \\
{[0.0244]}\end{array}$ & & & & $\begin{array}{c}19.955 \\
{[0.2325]}\end{array}$ \\
\hline & 1 & $\begin{array}{c}10.204 \\
{[0.1198]}\end{array}$ & $\begin{array}{c}6.604 \\
{[0.3982]}\end{array}$ & $\begin{array}{c}6.713 \\
{[0.3858]}\end{array}$ & $\begin{array}{c}6.559 \\
{[0.4033]}\end{array}$ & $\begin{array}{c}8.789 \\
{[0.1990]}\end{array}$ & $\begin{array}{c}10.348 \\
{[0.1136]}\end{array}$ & $\begin{array}{c}7.598 \\
{[0.2949]}\end{array}$ & $\begin{array}{c}9.795 \\
{[0.1393]}\end{array}$ & & $\begin{array}{c}9.678 \\
{[0.1453]}\end{array}$ & $\begin{array}{c}4.216 \\
{[0.7117]}\end{array}$ & $\begin{array}{c}7.113 \\
{[0.3426]}\end{array}$ \\
\hline \multirow{2}{*}{ 1_PDL } & 0 & $\begin{array}{c}25.760 \\
{[0.0496]} \\
\end{array}$ & $\begin{array}{c}27.917 \\
{[0.0252]} \\
\end{array}$ & $\begin{array}{c}32.342 \\
{[0.0055]}\end{array}$ & $\begin{array}{l}24.246 \\
{[0.0773]}\end{array}$ & $\begin{array}{c}33.068 \\
{[0.0042]}\end{array}$ & $\begin{array}{c}30.856 \\
{[0.0094]}\end{array}$ & $\begin{array}{c}19.461 \\
{[0.2595]}\end{array}$ & & & & & \\
\hline & 1 & $\begin{array}{c}8.388 \\
{[0.2281]}\end{array}$ & $\begin{array}{c}9.194 \\
{[0.1728]}\end{array}$ & $\begin{array}{c}9.881 \\
{[0.1350]}\end{array}$ & $\begin{array}{c}8.823 \\
{[0.1966]}\end{array}$ & $\begin{array}{c}6.842 \\
{[0.3715]}\end{array}$ & $\begin{array}{c}7.908 \\
{[0.2671]}\end{array}$ & $\begin{array}{c}6.217 \\
{[0.4438]}\end{array}$ & $\begin{array}{c}8.498 \\
{[0.2197]}\end{array}$ & $\begin{array}{c}7.930 \\
{[0.2652]}\end{array}$ & $\begin{array}{c}9.311 \\
{[0.1657]}\end{array}$ & $\begin{array}{c}7.106 \\
{[0.3434]}\end{array}$ & $\begin{array}{c}10.276 \\
{[0.1166]}\end{array}$ \\
\hline \multirow{2}{*}{ 1_POM } & 0 & $\begin{array}{c}28.919 \\
{[0.0182]}\end{array}$ & $\begin{array}{c}20.036 \\
{[0.2283]}\end{array}$ & $\begin{array}{c}19.507 \\
{[0.2570]}\end{array}$ & $\begin{array}{c}30.122 \\
{[0.0121]}\end{array}$ & $\begin{array}{c}38.705 \\
{[0.0005]}\end{array}$ & $\begin{array}{c}22.231 \\
{[0.1337]}\end{array}$ & $\begin{array}{c}28.950 \\
{[0.0180]}\end{array}$ & $\begin{array}{c}28.415 \\
{[0.0215]}\end{array}$ & $\begin{array}{c}20.239 \\
{[0.2179]}\end{array}$ & $\begin{array}{l}21.114 \\
{[0.1770]}\end{array}$ & $\begin{array}{c}17.457 \\
{[0.3894]}\end{array}$ & $\begin{array}{c}21.383 \\
{[0.1657]}\end{array}$ \\
\hline & 1 & $\begin{array}{c}9.456 \\
{[0.1574]}\end{array}$ & $\begin{array}{c}7.280 \\
{[0.3256]}\end{array}$ & $\begin{array}{c}6.914 \\
{[0.3638]}\end{array}$ & $\begin{array}{c}10.175 \\
{[0.1211]}\end{array}$ & $\begin{array}{c}7.400 \\
{[0.3138]}\end{array}$ & $\begin{array}{c}7.948 \\
{[0.2637]}\end{array}$ & $\begin{array}{c}7.823 \\
{[0.2746]}\end{array}$ & $\begin{array}{c}9.680 \\
{[0.1452]}\end{array}$ & $\begin{array}{c}6.093 \\
{[0.4591]}\end{array}$ & $\begin{array}{c}7.833 \\
{[0.2737]}\end{array}$ & $\begin{array}{c}6.385 \\
{[0.4237]}\end{array}$ & $\begin{array}{c}8.083 \\
{[0.2523]}\end{array}$ \\
\hline \multirow{2}{*}{ 1_SL } & 0 & $\begin{array}{c}22.922 \\
{[0.1114]}\end{array}$ & $\begin{array}{c}25.524 \\
{[0.0532]}\end{array}$ & $\begin{array}{c}17.675 \\
{[0.3738]}\end{array}$ & $\begin{array}{l}22.314 \\
{[0.1308]}\end{array}$ & $\begin{array}{c}29.375 \\
{[0.0156]}\end{array}$ & $\begin{array}{c}26.386 \\
{[0.0409]}\end{array}$ & $\begin{array}{l}25.498 \\
{[0.0536]}\end{array}$ & $\begin{array}{c}23.027 \\
{[0.1083]}\end{array}$ & $\begin{array}{c}25.281 \\
{[0.0572]}\end{array}$ & $\begin{array}{c}23.240 \\
{[0.1022]}\end{array}$ & $\begin{array}{c}15.631 \\
{[0.5301]}\end{array}$ & $\begin{array}{c}18.734 \\
{[0.3030]}\end{array}$ \\
\hline & 1 & $\begin{array}{c}7.803 \\
{[0.2763]}\end{array}$ & $\begin{array}{c}10.334 \\
{[0.1141]}\end{array}$ & $\begin{array}{c}5.847 \\
{[0.4901]}\end{array}$ & $\begin{array}{c}9.969 \\
{[0.1307]}\end{array}$ & $\begin{array}{c}6.427 \\
{[0.4186]}\end{array}$ & $\begin{array}{c}7.867 \\
{[0.2707]}\end{array}$ & $\begin{array}{c}7.614 \\
{[0.2935]}\end{array}$ & $\begin{array}{c}7.969 \\
{[0.2619]}\end{array}$ & $\begin{array}{c}8.310 \\
{[0.2340]}\end{array}$ & $\begin{array}{c}9.622 \\
{[0.1483]}\end{array}$ & $\begin{array}{c}6.079 \\
{[0.4608]}\end{array}$ & $\begin{array}{c}5.217 \\
{[0.5736]}\end{array}$ \\
\hline \multirow{2}{*}{ 1_SW } & 0 & $\begin{array}{c}24.351 \\
{[0.0750]}\end{array}$ & $\begin{array}{c}16.321 \\
{[0.4751]}\end{array}$ & $\begin{array}{c}17.351 \\
{[0.3970]}\end{array}$ & $\begin{array}{c}16.724 \\
{[0.4440]}\end{array}$ & $\begin{array}{c}21.458 \\
{[0.1627]}\end{array}$ & & $\begin{array}{c}16.405 \\
{[0.4686]}\end{array}$ & $\begin{array}{c}15.703 \\
{[0.5243]}\end{array}$ & $\begin{array}{c}21.876 \\
{[0.1465]}\end{array}$ & $\begin{array}{c}15.460 \\
{[0.5439]}\end{array}$ & $\begin{array}{c}14.306 \\
{[0.6376]}\end{array}$ & $\begin{array}{c}34.361 \\
{[0.0026]}\end{array}$ \\
\hline & 1 & $\begin{array}{c}10.830 \\
{[0.0946]}\end{array}$ & $\begin{array}{c}6.684 \\
{[0.3891]}\end{array}$ & $\begin{array}{c}6.514 \\
{[0.4085]}\end{array}$ & $\begin{array}{c}5.414 \\
{[0.5470]}\end{array}$ & $\begin{array}{c}5.535 \\
{[0.5308]}\end{array}$ & $\begin{array}{c}9.634 \\
{[0.1477]}\end{array}$ & $\begin{array}{c}6.261 \\
{[0.4385]}\end{array}$ & $\begin{array}{c}5.599 \\
{[0.5223]}\end{array}$ & $\begin{array}{c}6.028 \\
{[0.4672]}\end{array}$ & $\begin{array}{c}5.699 \\
{[0.5092]}\end{array}$ & $\begin{array}{c}4.705 \\
{[0.6441]}\end{array}$ & $\begin{array}{c}9.779 \\
{[0.1401]}\end{array}$ \\
\hline \multirow{2}{*}{ 1_W-M } & 0 & $\begin{array}{c}27.677 \\
{[0.0273]}\end{array}$ & $\begin{array}{c}29.602 \\
{[0.0144]}\end{array}$ & $\begin{array}{c}34.640 \\
{[0.0024]}\end{array}$ & $\begin{array}{c}29.814 \\
{[0.0134]}\end{array}$ & $\begin{array}{c}35.363 \\
{[0.0018]}\end{array}$ & $\begin{array}{c}32.241 \\
{[0.0057]}\end{array}$ & $\begin{array}{c}21.254 \\
{[0.1711]}\end{array}$ & $\begin{array}{c}26.435 \\
{[0.0403]}\end{array}$ & & $\begin{array}{c}28.360 \\
{[0.0218]}\end{array}$ & $\begin{array}{c}17.902 \\
{[0.3579]}\end{array}$ & $\begin{array}{c}40.418 \\
{[0.0002]}\end{array}$ \\
\hline & 1 & $\begin{array}{c}8.393 \\
{[0.2276]}\end{array}$ & $\begin{array}{c}8.980 \\
{[0.1862]}\end{array}$ & $\begin{array}{c}9.862 \\
{[0.1359]}\end{array}$ & $\begin{array}{c}9.715 \\
{[0.1434]}\end{array}$ & $\begin{array}{c}6.844 \\
{[0.3714]}\end{array}$ & $\begin{array}{c}7.946 \\
{[0.2639]}\end{array}$ & $\begin{array}{c}5.828 \\
{[0.4926]}\end{array}$ & $\begin{array}{c}8.491 \\
{[0.2203]} \\
\end{array}$ & $\begin{array}{c}8.269 \\
{[0.2373]} \\
\end{array}$ & $\begin{array}{c}9.515 \\
{[0.1541]} \\
\end{array}$ & $\begin{array}{c}6.671 \\
{[0.3906]}\end{array}$ & $\begin{array}{c}9.798 \\
{[0.1391]}\end{array}$ \\
\hline \multirow{2}{*}{ 1_WLK } & 0 & $\begin{array}{c}23.138 \\
{[0.1051]}\end{array}$ & $\begin{array}{c}17.864 \\
{[0.3605]}\end{array}$ & $\begin{array}{c}19.508 \\
{[0.2569]}\end{array}$ & $\begin{array}{c}22.221 \\
{[0.1340]}\end{array}$ & $\begin{array}{c}29.172 \\
{[0.0167]}\end{array}$ & $\begin{array}{c}12.097 \\
{[0.8036]}\end{array}$ & $\begin{array}{c}15.540 \\
{[0.5374]}\end{array}$ & $\begin{array}{c}21.883 \\
{[0.1462]}\end{array}$ & $\begin{array}{c}24.831 \\
{[0.0653]}\end{array}$ & $\begin{array}{c}22.397 \\
{[0.1280]}\end{array}$ & $\begin{array}{c}14.719 \\
{[0.6041]}\end{array}$ & $\begin{array}{c}20.686 \\
{[0.1962]}\end{array}$ \\
\hline & 1 & $\begin{array}{c}9.658 \\
{[0.1464]}\end{array}$ & $\begin{array}{c}7.497 \\
{[0.3045]}\end{array}$ & $\begin{array}{c}6.823 \\
{[0.3736]}\end{array}$ & $\begin{array}{c}8.971 \\
{[0.1868]}\end{array}$ & $\begin{array}{c}7.354 \\
{[0.3183]}\end{array}$ & $\begin{array}{c}3.858 \\
{[0.7600]}\end{array}$ & $\begin{array}{c}6.103 \\
{[0.4579]}\end{array}$ & $\begin{array}{c}9.792 \\
{[0.1394]}\end{array}$ & $\begin{array}{c}9.358 \\
{[0.1630]}\end{array}$ & $\begin{array}{c}10.282 \\
{[0.1164]}\end{array}$ & $\begin{array}{c}5.472 \\
{[0.5392]}\end{array}$ & $\begin{array}{c}6.757 \\
{[0.3810]}\end{array}$ \\
\hline \multirow{2}{*}{ 1_ZP } & 0 & $\begin{array}{c}26.275 \\
{[0.0424]}\end{array}$ & $\begin{array}{c}19.584 \\
{[0.2526]}\end{array}$ & $\begin{array}{c}18.994 \\
{[0.2870]}\end{array}$ & $\begin{array}{c}30.259 \\
{[0.0115]}\end{array}$ & $\begin{array}{c}35.563 \\
{[0.0017]}\end{array}$ & $\begin{array}{c}13.488 \\
{[0.7025]}\end{array}$ & $\begin{array}{c}16.775 \\
{[0.4401]}\end{array}$ & $\begin{array}{c}17.891 \\
{[0.3587]}\end{array}$ & $\begin{array}{c}15.833 \\
{[0.5139]}\end{array}$ & $\begin{array}{c}18.793 \\
{[0.2993]}\end{array}$ & $\begin{array}{c}16.564 \\
{[0.4563]}\end{array}$ & $\begin{array}{c}23.658 \\
{[0.0912]}\end{array}$ \\
\hline & 1 & $\begin{array}{c}9.891 \\
{[0.1345]}\end{array}$ & $\begin{array}{c}8.695 \\
{[0.2055]}\end{array}$ & $\begin{array}{c}4.804 \\
{[0.6303]}\end{array}$ & $\begin{array}{c}10.460 \\
{[0.1089]}\end{array}$ & $\begin{array}{c}7.546 \\
{[0.2998]}\end{array}$ & $\begin{array}{c}4.626 \\
{[0.6550]}\end{array}$ & $\begin{array}{c}4.962 \\
{[0.6084]}\end{array}$ & $\begin{array}{c}5.440 \\
{[0.5434]}\end{array}$ & $\begin{array}{c}5.669 \\
{[0.5132]}\end{array}$ & $\begin{array}{c}8.538 \\
{[0.2168]}\end{array}$ & $\begin{array}{c}7.376 \\
{[0.3162]}\end{array}$ & $\begin{array}{c}7.455 \\
{[0.3085]}\end{array}$ \\
\hline
\end{tabular}




\section{References}

Antonioli, Federico, Monia Ben Kaabia, Fillipo Arfini, and José M. Gil. 2018. Price transmission dynamics for quality-certified food products: A comparison between conventional and organic fluid milk in Italy. Agribusiness 35: 374-93. [CrossRef]

Bakucs, Zoltan L., and Imre Fertö. 2007. Spatial Integration on the Hungarian Milk Market. Paper presented at the 104th Seminar of European Association of Agricultural Economists, Budapest, Hungary, September 5-8.

Bakucs, Zoltan L., Zsófia Benedek, and Imre Fertö. 2019. Spatial Price Transmission and Trade in the European Dairy Sector. AGRIS on-line Papers in Economics and Informatics 11: 13-20. [CrossRef]

Bakucs, Zoltan L., Jan Falkowski, and Imre Fertö. 2010. Milk Market Integration between Hungary and Poland. Paper presented at the 84th Annual Conference of Agricultural Economics Society, Edinburgh, Scotland, UK, March 29-31.

Barrett, Christopher B. 2008. Spatial Market Integration. In The New Palgrave Dictionary of Economics, 2nd ed. Edited by Lawrence E. Blume and Steven Durlauf. London: Palgrave Macmillan, Available online: https:/ /ssrn.com/abstract=1142520 (accessed on 22 October 2021).

Baulch, Bob. 1997. Transfer Costs, Spatial Arbitrage, and Testing for Food Market Integration. American Journal of Agricultural Economics 79: 477-87. [CrossRef]

Bełdycka-Bórawska, Aneta, Piotr Bórawski, Marta Guth, Andrzej Parzonko, Tomasz Rokicki, Bogdan Klepacki, Marcin Wysokiński, Agnieszka Maciagg, and James William Dunn. 2021. Price changes of dairy products in the European Union. Agricultural Economics-Czech 67: 373-81. [CrossRef]

Benedek, Zsofia, Zoltan Bakucks, Jan Falkowki, and I. Imre Fertő. 2017. Intra-EU trade of dairy products: Insights from network analysis. Studies in Agricultural Economics 119: 91-97. [CrossRef]

Bórawski, Piotr, Marta Guth, Wojciech Truszkowski, Dagmara Zuzek, Aneta Beldycka-Borawska, Bartosz Mickiewicz, Elzbieta Szymanska, Jayson K. Harper, and James William Dunn. 2020a. Milk price changes in Poland in the context of the Common Agricultural Policy. Agricultural Economics-Czech 66: 19-26. [CrossRef]

Bórawski, Piotr, Aneta Beldycka-Borawska, Adam Pawlewicz, Jayson K. Harper, Bogdan Klepački, Agnieszka Brelik, and Ireneusz Zuchowski. 2020b. Impact of new member accession to the European Union on food trade. European Research Studies Journal XXIII: 149-59. [CrossRef]

Bórawski, Piotr, Marta Guth, Andrzej Parzonko, Tomasz Rokicki, Aleksandra Perkowska, and James William Dunn. 2021. Price volatility of milk and dairy products in Poland after accession to the EU. Agricultural Economics-Czech 67: 111-19. [CrossRef]

Čechura, Lukáš, and Zdeňka Žáková Kroupová. 2021. Technical Efficiency in the European Dairy Industry: Can We Observe Systematic Failures in the Efficiency of Input Use? Sustainability 13: 1830. [CrossRef]

Čechura, Lukáš, Zdeňka Žáková Kroupová, and Irena Benešová. 2021. Productivity and Efficiency in European Milk Production: Can We Observe the Effects of Abolishing Milk Quotas? Agriculture 11: 835. [CrossRef]

Chalmers, Neil, Cesar Revoredo-Giha, and Charles Jumbe. 2019. Measuring the Degree of Integration in the Dairy Products Market in Malawi. Social Sciences 8: 66. [CrossRef]

CLAL.IT. 2021. Italian Dairy Economic Consulting. Available online: https://www.clal.it/en/index.php (accessed on 3 November 2021).

Cournot, Augustin A. 1897. Researches into the Mathematical Principles of the Theory of Wealth. New York: The MacMillan Company, pp. 51-52. First published 1838.

Czech Statistical Office. 2021. Cross-Border Movements of Goods. Available online: https:/ /apl.czso.cz/pll/stazo/STAZO.STAZO? jazyk=EN\&prvni=N (accessed on 27 October 2021).

Domagała, Joanna. 2020. Links between SMP prices in Poland and selected foreign markets. Annals of the Polish Association of Agricultural and Agribusiness Economists 22: 44-52. [CrossRef]

Domagała, Joanna. 2021. Links between the price of butter in Poland and in selected foreign markets. Research Papers of Wroctaw University of Economics 65: 13-25. [CrossRef]

Dwyer, Gerald P., and Myles S. Wallace. 1992. Cointegration and market efficiency. Journal of International Money and Finance 11: 318-27. [CrossRef]

Elliott, G., Thomas. J. Rothenberg, and James Stock. 1996. Efficient tests for an autoregressive unit root. Econometrica 64: 813-36. [CrossRef]

Eurostat. 2021a. Economic Accounts for Agriculture_-Values at Current Prices [aact_eaa01]. Last Update: 9 April 2021. Available online: https:/ / appsso.eurostat.ec.europa.eu/nui/show.do?dataset=aact_eaa01\&lang=en (accessed on 24 October 2021).

Eurostat. 2021b. Annual Detailed Enterprise Statistics for Industry (NACE Rev. 2, B-E) [sbs_na_ind_r2]. Last Update: 8 March 2021. Available online: https://appsso.eurostat.ec.europa.eu/nui/show.do?dataset=sbs_na_ind_r2\&lang=en (accessed on 24 October 2021).

Eurostat. 2021c. Production and Utilization of Milk on the Farm-Annual Data [apro_mk_farm]. Last Update: 11 October 2021. Available online: https:/ / ec.europa.eu/eurostat/web/products-datasets/- /apro_mk_farm (accessed on 24 October 2021).

Eurostat. 2021d. Bovine Population-Annual Data [apro_mt_lscatl]. Last Update: 18 October 2021. Available online: https: / / appsso.eurostat.ec.europa.eu/nui/show.do?dataset=apro_mt_lscatl\&lang=en (accessed on 24 October 2021).

Eurostat. 2021e. Milk and Milk Products-30 Years of Quotas. Available online: https:/ / ec.europa.eu/eurostat/statistics-explained/ index.php/Archive:Milk_and_milk_products_-30_years_of_quotas (accessed on 16 December 2021). 
Fackler, Paul L. 1996. Spatial Price Analysis: A Methodological Review. Paper presented at the NCR-134 Conference on Applied Commodity Price Analysis, Forecasting, and Market Risk Management, Chicago, IL, USA, April 22-23. Available online: http:/ / www.farmdoc.uiuc.edu/nccc134 (accessed on 22 October 2021).

FADN. 2021. FADN Public Database (SO). Available online: https://agridata.ec.europa.eu/extensions/FADNPublicDatabase/ FADNPublicDatabase.html (accessed on 24 October 2021).

Fałkowski, Jan. 2010. Price transmission and market power in a transition context: Evidence from the Polish fluid milk sector. Post-Communist Economies 22: 513-29. [CrossRef]

Fallert, Richard F., Harold W. Lough, and Robert L. Beck. 1978. Food Chain Integration and Fluid Milk Marketing. Journal of Dairy Science 61: 983-87. [CrossRef]

FAO. 2021. Data. Trade. Available online: https://www.fao.org/faostat/en/\#data/TM (accessed on 25 November 2021).

Fetter, Frank A. 1924. The economic law of market areas. The Quarterly Journal of Economics 8: 520-29. [CrossRef]

Fousekis, Panos. 2018. Price interrelationships in the EU cow milk markets: Evidence from rank-based cointegration tests. Outlook on Agriculture 47: 101-7. [CrossRef]

Fousekis, Panos, and Emmanouil Trachanas. 2016. Price transmission in the international skim milk powder markets. Applied Economics 48: 5233-45. [CrossRef]

Frederico, Giovanni. 2007. Market integration and market efficiency: The case of 19th century Italy. Explorations in Economic History 44: 293-316. [CrossRef]

García-Hiernaux, Alfredo, David E. Guerrero, and Michael McAleer. 2016. Market integration dynamics and asymptotic price convergence in distribution. Economic Modeling 52: 913-25. [CrossRef]

Gitau, Raphael, and Ferdi Meyer. 2018. Spatial market integration in the era of high food prices. A case of surplus and deficit maize markets in Kenya. Agrekon 57: 251-65. [CrossRef]

Gluschenko, Konstantin. 2021. Spatial pattern of Russia's market integration. Spatial Economic Analysis 16: 449-70. [CrossRef]

González-Rivera, Gloria, and Steven M. Helfand. 2001. The Extent, Pattern, and Degree of Market Integration: A Multivariate Approach for the Brazilian Rice Market. American Journal of Agricultural Economics 83: 576-92. [CrossRef]

Goodwin, Barry K., and Ted C. Schroeder. 1991. Cointegration Tests and Spatial Price Linkages in Regional Cattle Markets. American Journal of Agricultural Economics 73: 452-64. [CrossRef]

Goodwin, Barry K., Thomas J. Grennes, and Christine McCurdy. 1999. Spatial price dynamics and integration in russian food markets. The Journal of Policy Reform 3: 157-93. [CrossRef]

Goodwin, Barry K., Matthew T. Holt, and Jeffrey P. Prestemon. 2021. Semi-parametric models of spatial market integration. Empirical Economics 61: 2335-61. [CrossRef]

Granger, C. W. J. 1969. Investigating Causal Relations by Econometric Models and Cross-spectral Methods. Econometrica 37: 424-38. [CrossRef]

Habte, Zewdie. 2017. Spatial market integration and price transmission for papaya markets in Ethiopia. Journal of Development and Agricultural Economics 9: 129-36. [CrossRef]

Hamulczuk, Mariusz. 2020. Spatial Integration of Agricultural Commodity Markets-Methodological Problems. Problems of Agricultural Economics 2: 32-52. [CrossRef]

Hamulczuk, Mariusz, Oksana Makarchuk, and Edgardo Sica. 2019. Searching for market integration: Evidence from Ukrainian and European Union rapeseed markets. Land Use Policy 87: 104078. [CrossRef]

Hillen, Judith, and Stephan von Cramon-Taubadel. 2019. Protecting the Swiss milk market from foreign price shocks: Public border protection vs. quality diferentiation. Agribusiness 35: 516-36. [CrossRef]

Hou, Shiying, and Liangrong Song. 2021. Market Integration and Regional Green Total Factor Productivity: Evidence from China's Province-Level Data. Sustainability 13: 472. [CrossRef]

Ihle, Rico, Bernhard Brümmer, and Stanly R. Thompson. 2012. Structural change in European calf markets: Decoupling and the blue tongue disease. European Review of Agricultural Economics 39: 157-80. [CrossRef]

Jacks, David S., Kevin H. O'Rourke, and Jeffrey G. Williamson. 2011. Commodity price volatility and world market integration since 1700. The Review of Economics and Statistics 93: 800-13. [CrossRef]

Jaramillo-Villanueva, José Luis, and Adriana Palacios-Orozco. 2019. Vertical and spatial price transmission in the Mexican and international milk market. Revista mexicana de ciencias pecuarias 10: 623-42. [CrossRef]

Jha, Awadhesh K., Krishna M. Singh, and Ritambhara K. P. Singh. 2013. Wholesale Milk Markets: A Study of Market Integration in Indian Markets. MPRA Paper No. 47721. Available online: https://mpra.ub.uni-muenchen.de/47721/ (accessed on 26 October 2021).

Katrakilidis, Constantinos. 2008. Testing for market integration and the law of one price: An application to selected European milk markets. International Journal of Economic Research 5: 93-104.

Kharin, Sergei. 2018. Price Transmission Analysis: The Case of Milk Products in Russia. AGRIS On-Line Papers in Economics and Informatics 10: 15-23. [CrossRef]

Klepačka, Anna M., Wojciech J. Florkowski, and Cesar Revoredo-Giha. 2021. Can Family Farms Depend on Price Information? Testing Butter and Curd Price Integration in Poland. Agriculture 11: 434. [CrossRef]

Kumar, Anil, and Rojani Mishra. 2017. The spatial integration of potato wholesale markets of Uttarakhand in India. SAARC Journal of Agriculture 14: 20-30. [CrossRef] 
Kussaiynor, Talgat A., and Zhazira O. Zhakupova. 2019. Forecasting the milk prices from a supply chain management perspective in the northern Kazakhstan. International Journal of Supply Chain Management 8: 851-58.

Listorti, Giulia, and Roberto Esposti. 2012. Horizontal Price Transmission in Agricultural Markets: Fundamental Concepts and Open Empirical Issues. Bio-Based and Applied Economics 1: 81-96. [CrossRef]

McNew, Kevin. 1996. Spatial Market Integration: Definition, Theory, and Evidence. Agricultural and Resource Economics Review 25: 1-11. [CrossRef]

Ministry of Agriculture of the Czech Republic. 2020. Situační a Výhledová Zpráva: Mléko. Available online: http:/ / eagri.cz/public/ web / file/670746/Mleko_2020_WEB.pdf (accessed on 24 October 2021).

Ministry of Agriculture of the Czech Republic. 2021. Komoditní Karta: Mléko-Červenec 2021. Available online: http:// eagri.cz/ public/web / file/685482/Komoditni_karta_Mleko_cervenec_2021.docx (accessed on 24 October 2021).

Ministry of Agriculture, Nature and Food Quality. 2018. Quick Scan Polish Dairy Sector. Available online: https://www. agroberichtenbuitenland.nl/binaries/agroberichtenbuitenland/documenten/publicaties/2020/10/21/poland-quick-scandairy-sector/Poland+dairy+quick+scan+Oct+2020.pdf (accessed on 24 October 2021).

Ministry of Agriculture, Nature and Food Quality. 2021. Poland: Market of Milk and Dairy Products. Available online: https: //www.agroberichtenbuitenland.nl/actueel/nieuws/2021/08/02/poland-market-of-milk-and-dairy-products (accessed on 24 October 2021).

Neusser, Klaus. 2016. Time Series Econometrics. Cham: Springer International Publishing, pp. 305-10.

Pan, Fanghui, and Cuixia Li. 2019. Evolution of Agricultural Spatial Market Integration: Evidence from the Hog Market in China. Journal of Agricultural and Applied Economics 51: 349-67. [CrossRef]

Philippidis, George, and Robert Waschik. 2019. Melitz Meets Milk: The Impact of Quota Abolition on EU Dairy Export Competitiveness. Journal of Agricultural Economics 70: 44-61. [CrossRef]

Phillips, Peter Charles Bonest, and Pierre Perron. 1988. Testing for a unit root in time series regression. Biometrika 75: 335-46. [CrossRef]

Polish Statistical Office. 2021. Procurement and Prices of Agricultural Products in 2001-21. Available online: https://stat.gov.pl/ obszary-tematyczne/rolnictwo-lesnictwo/rolnictwo/skup-i-ceny-produktow-rolnych-w-2020-roku,7,17.html (accessed on 3 November 2021).

Ravallion, Martin. 1986. Testing Market Integration. American Journal of Agricultural Economics 68: 102-8. [CrossRef]

Reziti, Ioanna. 2014. Price transmission analysis in the Greek milk market. SPOUDAI Journal of Economics and Business 64: 75-86.

Roman, Monika. 2017. Butter market integration between Poland and selected European Union countries. Roczniki Naukowe Stowarzyszenia Ekonomistow Rolnictwa i Agrobiznesu XIX: 169-74. [CrossRef]

Roman, Monika. 2018. Problems with the Logistics of Supplying Dairy Plants with Milk. Annals of the Polish Association of Agricultural and Agribusiness Economists 4: 162-67. [CrossRef]

Roman, Monika. 2020. Spatial integration of the milk market in Poland. Sustainability 12: 1471. [CrossRef]

Roman, Monika, and Michał Roman. 2020. Milk Market Integration between Poland and the EU Countries. Agriculture 10: 561. [CrossRef]

Rudinskaya, Tamara, Tomáš Hlavsa, and Martin Hruska. 2019. Estimation of technical efficiency of Czech farms operating in less favoured area. Agricultural Economics (Czech Republic) 65: 445-53. [CrossRef]

Serra, Teresa, and Barry K. Goodwin. 2003. Price transmission and asymmetric adjustment in the Spanish dairy sector. Applied Economics 35: 1889-99. [CrossRef]

Serra, Teresa, José M. Gil, and Barry K. Goodwin. 2006. Local Polynomial Fitting and Spatial Price Relationships: Price Transmission in EU Pork Markets. European Review of Agricultural Economics 33: 415-36. [CrossRef]

Sobczak, Wioleta, Rafał Zbyrowski, and Bolesław Borkowski. 2018. Spatial integration of vegetable wholesale markets in Poland on the selected example. Acta Scientiarum Polonorum. Seria: Oeconomia 17: 151-58. [CrossRef]

Sobczyński, Tadeusz, Anna M. Klepačka, Cesar Revoredo-Giha, and Wojciech J. Florkowski. 2015. Dairy farm cost efficiency in leading milk-producing regions in Poland. Journal of Dairy Science 98: 8294-307. [CrossRef]

Statistics Poland. 2021. Cow's Milk Production. Last Update: 9 September 2021. Available online: https://bdl.stat.gov.pl/BDL/dane/ podgrup/tablica (accessed on 24 October 2021).

Svanidze, Miranda, Linde Götz, and Dmytro Serebrennikov. 2021. The influence of Russia's 2010/2011 wheat export ban on spatial market integration and transaction costs of grain markets. Applied Economic Perspectives and Policy 2021: 13168. [CrossRef]

Thorsøe, Martin, Egon Noe, Damian Maye, Mauro Vigani, James Kirwan, Hannah Chiswell, Mikelis Grivins, Anda AdamsoneFiskovica, Talis Tisenkopfs, Emi Tsakalou, and et al. 2020. Responding to change: Farming system resilience in a liberalized and volatile European dairy market. Land Use Policy 99: 105029. [CrossRef]

Tłuczak, Agnieszka. 2012. Attempt to identify the causal relationship between the price of milk in selected countries. Acta Oeconomica et Informatica 15: 47-49.

Trnková, Gabriela, and Zdeňka Žáková Kroupová. 2020. Determinants of persistent and transient technical efficiency of milk production in EU. E+M Economics and Management 23: 39-54. [CrossRef]

Van Campenhout, Bjorn. 2007. Modelling trends in food market integration: Method and an application to Tanzanian maize markets. Food Policy 32: 112-27. [CrossRef]

Xue, Huidan, Chenguang Li, and Liming Wang. 2021. Spatial Price Dynamics and Asymmetric Price Transmission in Skim Milk Powder International Trade: Evidence from Export Prices for New Zealand and Ireland. Agriculture 11: 860. [CrossRef] 
Zdráhal, Ivo, and Věra Bečvářová. 2018. Entry into the Common Market of the European Union in Terms of Czech Republic's Foreign Trade with Dairy Products. Acta Universitatis Agriculturae et Silviculturae Mendelianae Brunensis 66: 605-16. [CrossRef]

Zuba-Ciszewska, Maria. 2018. Structural Changes in the Dairy Industry and Their Impact on the Efficiency of Dairies-A Polish Example. Paper presented at the International Scientific Conference "Economic Sciences for Agribusiness and Rural Economy", Warsaw, Poland, June 7-8. 